Portland State University

PDXScholar

$1-1-2003$

\title{
Women Adrift, Sporting Girls and the Unfortunate Poor: A Gendered History of Homelessness in Portland 1900-1929
}

Leanne Claire Serbulo

Portland State University

Follow this and additional works at: https://pdxscholar.library.pdx.edu/open_access_etds Let us know how access to this document benefits you.

\section{Recommended Citation}

Serbulo, Leanne Claire, "Women Adrift, Sporting Girls and the Unfortunate Poor: A Gendered History of Homelessness in Portland 1900-1929" (2003). Dissertations and Theses. Paper 741.

https://doi.org/10.15760/etd.741

This Thesis is brought to you for free and open access. It has been accepted for inclusion in Dissertations and Theses by an authorized administrator of PDXScholar. Please contact us if we can make this document more accessible: pdxscholar@pdx.edu. 


\section{THESIS APPROVAL}

The abstract and thesis of Leanne Claire Serbulo for the Master of Urban Studies were presented June 18, 2003 and accepted by the thesis committee and the school.

COMMITTEE APPROVALS:
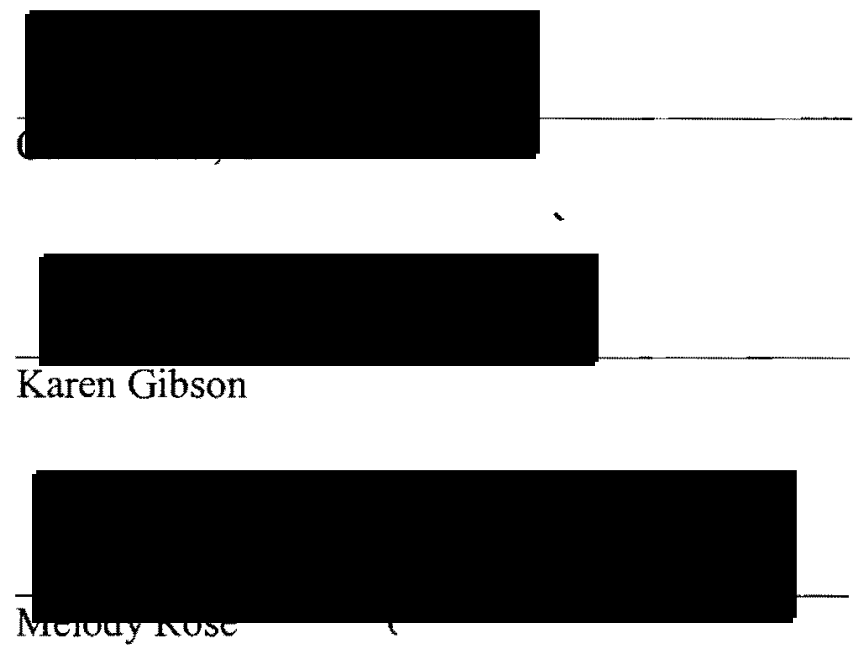

Representative of the Office of Graduate Studies

SCHOOL APPROVAL:

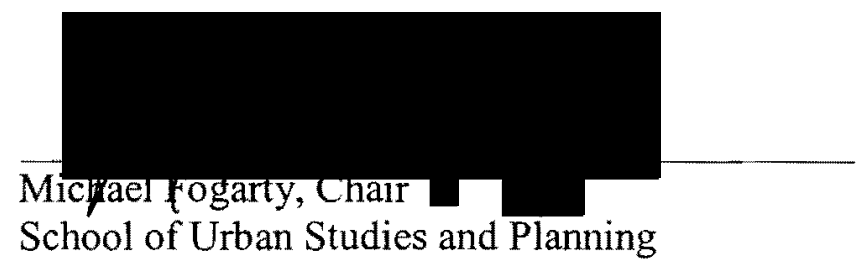




\begin{abstract}
An abstract of the thesis of Leanne Claire Serbulo for the Master of Urban Studies presented June 18, 2003
\end{abstract}

Title: Women Adrift, Sporting Girls and the Unfortunate Poor: A Gendered History of Homelessness in Portland 1900-1929.

This purpose of this study is to incorporate women into the history of homelessness. Women's experience is missing from the narrative of industrial era homelessness, which causes researchers to make a distinction between the modern day homeless population and its predecessors. This distinction prevents researchers from examining the long term structural causes of homelessness and analyzing the role homelessness plays in U.S. society.

This study explores the population characteristics and living conditions of three groups of women who were considered homeless during the early decades of the twentieth century in Portland. These groups include single working women who lived away from their family, prostitutes, and single mothers. This study also traces the development of charitable institutions and social welfare programs that arose to meet the needs of homeless women during this era and examines the relationships between homeless women and the reformers and charities that took up their cause.

The inclusion of women's experience into the history of early twentieth century homelessness necessitates a broadened definition of the homeless phenomenon. Women's homelessness during this era was both defined and 
determined by their family situation. Women who lived outside of the patriarchal family were considered homeless and suffered economic hardship because of their non-traditional living arrangements.

Incorporating an analysis of home back into homelessness will result in nongendered policy implications. Labor market remedies and affordable housing solutions are still needed, but changes to the structure of the household economy are also called for. The unpaid labor women traditionally perform must be socially and economically valued and the sexual division of labor within the home needs to be challenged. 
WOMEN ADRIFT, SPORTING GIRLS AND

THE UNFORTUNATE POOR:

A GENDERED HISTORY OF HOMELESSNESS

IN PORTLAND 1900-1929

by

LEANNE CLAIRE SERBULO

A thesis submitted in partial fulfillment of the requirements of the degree of

MASTER OF URBAN STUDIES

Portland State University

2003 


\section{DEDICATION}

This thesis is dedicated to the memory of Claire Rose Toth who taught me tolerance and passed on her love of reading. 
TABLE OF CONTENTS

CHAPTER

PAGE

List of Tables

iii

I INTRODUCTION 1

II DOWN AND OUT IN THE CITY OF ROSES 20

III WOMEN ADRIFT: WAGE EARNING WOMEN

ON THEIR OWN $\quad 32$

IV SPORTING GIRLS: THE PROSTITUTION

ALTERNATIVE $\quad 64$

V THE UNFORTUNATE POOR:

BREADWINNING WOMEN AND THEIR CHILDREN 90

VI CONCLUSIONS 115

$\begin{array}{ll}\text { References } & 127\end{array}$ 


\section{LIST OF TABLES}

TITLE

Primary Determinants of Homelessness According to Gender, 1990-1929

\section{PAGE}

13 


\section{CHAPTER I INTRODUCTION}

I'll be ever' where-wherever you look. Wherever they's a fight so hungry people can eat, I'll be there. Wherever they's a cop beatin' up a guy, I'll be there...I'll be in the way guys yell when they're mad an'-I'll be in the way kids laugh when they're hungry and they know supper's ready. An' when our folks eat the stuff they raise an' live in the houses they build-why I'll be there. ${ }^{1}$

The words of Steinbeck's hero Tom Joad continue to reverberate today as a rallying call for social and economic justice. The story of the Joads evoked public sympathy and raised national awareness about the plight of homeless families during the dustbowl. Tom Joad lives on in our cultural consciousness as a symbol of the resistance of the downtrodden. But where, in our collective memory, are the stories of Ma Joad, who presses the family's last dollar in the hands of her fleeing son, or Rose of Sharon Joad, who physically sustains the community at the end of the tale? The historical experiences of homeless women, like this fictional mother and sister, are the focus of this study. This research project examines homelessness among women in Portland during the first decades of the twentieth century. The primary question addressed is how did women experience homelessness in Portland from 1900 until $1929 ?$

Homelessness is an enduring social phenomenon that has plagued our nation since colonial times. Public awareness of the homeless waxed and waned over the last three centuries. The first recognition of homelessness as a national social problem occurred in the early 1800 s and it reemerged as a critical issue again the latter part of the nineteenth century. ${ }^{2}$ However, it wasn't until the Great Depression, when 
homeless families overwhelmed local social services, that the federal government enacted the first national legislation addressing the problems of homelessness and poverty. By the end of World War II, the suffering of the very poor had disappeared from the public view and it did not resurface until the recession of the early $1980 \mathrm{~s}$ when men and women were once again, visibly sleeping on city streets.

With the exception of the Great Depression, the history of homelessness has been researched and retold as a history of homeless men. While historians acknowledge women's presence among the ranks of the colonial homeless, women are absent from the conventional descriptions of the nineteenth and early twentieth century urban homeless who accompanied industrialization. ${ }^{3}$ The popular conceptualization of the homeless of this era is the hobo, or the male migratory or seasonal worker who utilized skid row institutions. This association of industrial era homelessness with marginal status in the labor market and the urban neighborhoods and services these laborers frequented leads to the omission of homeless women from the historical record. Not only were women less likely to be working for wages at this time, but rooming houses frequented by female laborers may not have been located within the tightly defined boundaries of the skid row neighborhood. ${ }^{4}$ Industrial era researchers and historians who studied skid row focused only on their male transient residents and failed to consider prostitutes and other women who lived and worked within the neighborhood as members of the skid row homeless community. ${ }^{5}$ Finally, social service organizations that arose to meet the needs of homeless women emerged separately and distinctly from skid row charities. ${ }^{6}$ 
Women's experience needs to be incorporated in the construction of the historical narrative of homelessness in the United States. The current male bias that dominates discussions of industrial era homelessness is historically inaccurate, which is reason enough to justify a reconsideration of past evidence. However, the history of homelessness also affects our understanding of current homelessness. The modern day homeless have been labeled the "new" homeless based, in part on the recent "appearance of significant numbers of women among the homeless."7 Stephanie Golden, who has researched the historical roots of women's homelessness, asserts that during the industrial era, women went to great lengths to conceal their homeless status. ${ }^{8}$ Therefore the idea that women were not part of the "old" homeless population may be a result of a flawed reading of history.

Divorcing the "new" homeless population from its "old" predecessors has far reaching implications. Above all, it creates a false division between the modern homeless population and its historic predecessors. This prevents contemporary researchers and advocates from examining homelessness over the long term, which could lead to a greater understanding of the structural roots of the problem and the role homelessness plays in United States society. Researchers who rely on the popularly accepted version of the history of homelessness to identify its structural roots will not be able take into account the unique, long standing causes of female homelessness. This will result in gendered policy suggestions that fail to incorporate remedies for women's poverty. 


\section{The Research on Women and Homelessness}

The female homeless were not studied or researched until the early 1980 s, when women emerged as an identifiable population on the streets. Like their male counterparts, women become homeless because of poverty, the lack of affordable housing, unemployment, urban economic transformations and the absence of a social safety net. ${ }^{9}$

It is not surprising given the density of women in poverty that female-headed households make up one of the fastest growing sectors of the current homeless population. In $199676 \%$ of the people who lived below the poverty level were women and children. ${ }^{10}$ Women's low incomes are a result of occupational segregation. Women are disproportionately confined to "pink collar" occupations, which pay less than traditionally male jobs. In 1999 , women only earned $72.2 \%$ of what men earned and two thirds of minimum wage workers were female. A disproportionate number of homeless women are African American, which coincides with the high poverty rates black women suffer. ${ }^{11}$ In the late 1990 s, black women's poverty rates were three times as high as their white female counterparts. ${ }^{12}$ Close to forty percent of the female homeless population faces the double burden of racism in addition to gender discrimination

Despite women's high poverty rates, Maxine Harris argues that the primary cause of homelessness in women is the patriarchal family structure. ${ }^{13}$ According to one researcher's study, over half of all homeless women lose their shelter due to domestic violence. ${ }^{14}$ In addition to domestic violence, $20 \%$ of the women interviewed 
became homeless after their male partner left, died, or was imprisoned. Experiencing family violence or sexual abuse in one's childhood also increases a women's risk for homelessness. Childhood abuse can lead to post traumatic stress disorder, which compromises its sufferers' abilities to cope with daily life.

In addition to abusive relationships, a woman's family status can increase her risk for homelessness. Pregnant women and mothers face higher probabilities of becoming homeless. ${ }^{15}$ Pregnant women and mothers with young children are discriminated against in hiring and child rearing responsibilities reduce the number of hours a woman is available to work to a much greater extent than it does fathers. Motherhood is a risk factor for homelessness, and the loss of shelter can lead to family disruption. Many women temporarily give up their children to relatives or foster care until they can find permanent housing.

Losing custody of children is just one way in which women's experience of homelessness differs from men's. Golden writes that homeless men found community in skid row neighborhoods, while homeless women have historically attempted to conceal their status. ${ }^{16}$ Julia Wardhough chronicles the physical reactions some women have to experiencing homelessness. They often undergo elaborate changes in the ways they dress, wear their hair or even how much they weigh in order to disappear while in public spaces. ${ }^{17}$ Women mask their homelessness in public in order to stay safe, but Harris asserts this process can strip homeless women of their identity, making it difficult for them to reconnect with society after they become housed. ${ }^{18}$ 


\section{The History of Women's Homelessness}

Homeless women are generally thought to be a modern phenomenon despite published evidence of their past existence. Bertha Thompson's autobiography of her travels as a female hobo in the 1920s and 1930s is the best-known historical account of female homelessness. Although 'Boxcar Bertha' met a few women while riding the rails, most of the homeless women she knew preferred to hitchhike rather than hop freights and tried to blend in with the local population instead of frequenting hobo jungles or the main stem of skid row. ${ }^{19}$

Bertha Thompson's firsthand observations about the nature of female homelessness during the early twentieth century contradict most researchers' historical categorizations of the homeless. Historians divide the narrative of homelessness in the United States into three distinct eras: the colonial era (pre Civil War), the industrial era (Civil War to the Depression) and post-industrial era (after 1980). ${ }^{20}$ The post World War II period from 1945-1980 is notably absent in the discourse on homelessness. Most of the literature assumes that homelessness was not a widespread problem at this time of economic expansion and that it was limited to the older white male population who lived on skid row.

Researchers describe the colonial era homeless as a diverse population that included single men, women, couples, families with children and the elderly. ${ }^{21}$ Townspeople received local government assistance to shelter the resident poor or to provide them food and bed in exchange for work. As the populations of the eastern seaboard grew, more colonial citizens took to the road to find land and work. The 
increased population of the wandering poor led towns to search for ways to escape the burden of supporting the poor, resulting in legislative distinctions and differential treatment of the transient and resident poor.

Urbanization and industrialization did not erase legislative distinctions between the resident and transient poor. The Industrial Revolution created a need for an army of transient, seasonal workers who harvested raw materials and led the expansion of the western frontier. ${ }^{22}$ In between seasonal jobs on the rural frontier, male workers gravitated to the city, where skid row institutions such as flophouses, burlesque shows, cheap lunch counters, taverns and employment agencies provided cheap lodging, food, entertainment and possibility of the next job. The completion of the continental railroad facilitated the movement of men across the country.

The industrial era was the age of the hobo and the tramp. Eric Monkkonen estimates that $10-20 \%$ of families in the United States had a member that tramped during the late nineteenth century. ${ }^{23}$ He subdivides this period of homelessness into two distinct eras. The heyday of the tramp lasted from the Civil War until the early 1920s. Work was plentiful and skid row emerged as a distinct cultural community. With the closing of the frontier and mechanization of manual labor in the 1920's, tramps became "marginal and defeated" and the only truly seasonal economic sector that remained was agriculture. Kenneth Allsop chronicled the subculture and daily life of the men who performed this seasonal industrial labor. He claimed their geographic mobility allowed the public to ignore their living and working conditions, resulting in a class of people "allowed to move horizontally but not vertically."24 
The focus on the white, male seasonal worker during the industrial era has led scholars to ignore homelessness among other sectors of the population. Kenneth Kusmer's recent work is one of the first to challenge these assumptions by incorporating the experiences of destitute African Americans into this chronology. Skid row neighborhoods were segregated and similar lodging house and hotel accommodations were found at this time within African American neighborhoods. Because the skid row researchers traditionally only looked at white neighborhoods, contemporary scholars assume that the disproportionate representation of non-whites in the homeless population is characteristic of a new phenomenon. ${ }^{25}$

Although Kusmer acknowledges that homeless women tended to be less mobile and visible than their male counterparts, he does not elaborate much on the female experience with homelessness during the industrial era. ${ }^{26}$ Despite the evidence uncovered by Stephanie Golden and the observations in Bertha Thompson's autobiography that homeless women tried to blend in with the general population and avoided skid row institutions, Kusmer and other historians continue to use records from institutions dominated by male transients such as data from municipal lodging houses, skid row Census tracts, and vagrancy arrests to identify the composition of the industrial era homeless population.

Unlike transient men, homeless women tended to remain in one city during the industrial era. ${ }^{27}$ Single, rural women who migrated to the city to work often ended up living in cheap lodging houses or at times, on the streets. During this age, an unescorted woman in public was assumed to be a prostitute, so these 'women adrift' 
took pains to hide their status. Some homeless women turned to prostitution as a means of economic support; but many more just lived in the same lodging houses or cheap hotels prostitutes frequented. The persistent presence of prostitution at this time led to the establishment of a network of rescue homes and charity organizations whose primary mission was to reform prostitutes and prevent other women from entering the sex trade. ${ }^{28}$ These charity organizations, which ultimately led to the criminalization of prostitution, were the only charitable institutions available to single women who lacked economic resources. Because the history of women's homelessness is so intertwined with the history of prostitution, Golden believes that "homelessness issues are different for women and need to be examined separately." 29

Are the dichotomies between the today's new homeless and those of the industrial era really so strong? Kenneth Kusmer has challenged the racial bias in the historical literature on homelessness. Lynn Weiner and Stephanie Golden have laid the groundwork to construct a portrait of women's experiences with homelessness during the industrial era. However, Weiner primarily focuses on female tramps and Golden is concerned with the society's ongoing marginalization of homeless women. Little scholarly attention has been paid to the history of homeless people, let alone subpopulations within the homeless. While there is evidence that women's experience with homelessness differed from men's, a gendered analysis of this phenomenon has yet to be written. 


\section{Incorporating Women into the History of Homelessness: Research}

\section{Questions, Methodologies, and Operational Definitions}

The purpose of this research project is to incorporate women into the historical narrative of industrial era homelessness. The major question to be explored is how did women experience homelessness in Portland from 1900-1929? Women's experience with homelessness is defined by three sub questions. Who were homeless women? What charities and social welfare programs that existed to serve them? What was the relationship between charity workers and reformers and the female poor? Before any questions can be addressed, however, the term homelessness first needs to be defined.

The accepted definitions of homelessness for the era reflect the white male bias of early social science researchers. In order to be considered homeless, one must primarily be unemployed and secondarily be disconnected from kin. Nels Anderson, a former hobo and early sociologist who studied skid row, categorized the homeless according to their relationship to the labor market. Anderson understood the important economic role transitory male laborers played in opening up the western frontier. His five classes of the homeless included: the seasonal laborer, the hobo or migratory casual laborer, the home guard or non-migratory casual laborer, the tramp or migratory non-worker, and the bum. ${ }^{30}$ He went on to say that the hobos were a group of individuals "without community," single men who lived apart from their family. ${ }^{31}$ While Anderson's definition noted the absence of traditional family structures among the homeless, he primarily illuminated the important role homeless men played in the capitalist system. By doing this, he failed to incorporate women, whose defining 
characteristic at this time was detachment from the labor market, into his definition of the homeless population.

Two decades before Andersons's participant observation of Chicago's skid row homeless men, Anne Solenberger, a social worker, published a study of her work with one thousand homeless men in that city. She categorized homeless men according to their level of dependency upon relief including: the self supporting or temporarily unemployed, the temporarily dependent who were sick, injured or newly arrived in town, the chronically dependent who were disabled, aged or alcoholics, and the parasitic who were imposters, beggars or bums. ${ }^{32}$ Just as Anderson's classes reflect his academic interest in the labor market, Solenberger's categorizations reveal her concern with the dispensation of charity. Like Anderson, Solenberger recognized the role family status played in determining who became homeless, she states, "the term homeless man might be applied to any man who has left one family group and not yet identified himself with another."

Disaffiliation was also an essential focus in later writings on skid row and homelessness. Donald Bogue perceived homeless men on skid row in the early sixties to be lacking social ties. ${ }^{33}$ Howard Bahr defined the homeless ten years later by their "detachment from society characterized by the absence or attenuation of the affiliative bonds that link settled persons to a network of interconnected social structures." ${ }^{34}$ Blumberg, Shipley and Moor go on to reject the geographical notion of skid row, where homeless men were concentrated, in favor of a definition of skid row as "a human condition." 35 Skid row people are defined by their poverty, life "outside of 
normal family relationships," residence in low cost housing, high rates of victimization and arrest, a failure to make deep social connections and an inability to escape their situation or and a future of "downward mobility."

These definitions of homelessness are confusing when one considers the modern context where millions each year experience a literal lack of shelter. The homeless that researchers studied during the early to mid twentieth century were usually housed, although in substandard conditions. What defined these men and women apart from the ranks of the urban poor was their family status and tenuous connection to the labor market and/or inability to settle in one geographical place. Homelessness during the industrial era was not defined by one's lack of shelter, but rather by a combination of economic deprivation and family estrangement. The emphasis placed on the family status of the homeless of this era makes an even stronger case for the inclusion of women into the historical record. For women during this time, family status was not only a social relationship but also an economic one. A woman in a non-patriarchal living arrangement had a much greater chance of experiencing poverty than did her married counterpart.

The operational definition I used to help identify homeless women in this era is a non gendered version of Solenberger's: "the term homeless might be applied to any wo/man who has left one family group and not yet identified her/himself with another." ${ }^{36}$ This definition emerged in the course of the research with the growth of my understanding of the conceptualization of homelessness in that period. Homelessness was defined by both poverty and disaffiliation. For men, economic 
status played a much greater role in determining homelessness (See Table 1). Most homeless men were temporarily unemployed or permanently unemployable.

Estrangement from family and the choice to remain single or childless was largely a result of their economic deprivation. Men who were tenuously employed could not afford to support a wife or children.

Table 1: PRIMARY DETERMINANTS OF HOMELESSNESS

ACCORIDNG TO GENDER FROM 1900-1929

GENDER DETERMINANTS OF HOMELESSNESS

\begin{tabular}{|c|c|c|}
\hline & $\begin{array}{l}\text { ECONOMIC } \\
\text { DEPRIVATION } \\
\text { (WORK) }\end{array}$ & $\begin{array}{l}\text { FAMILY } \\
\text { ESTRANGMENT } \\
\text { (HOME) }\end{array}$ \\
\hline MEN & $\mathrm{X}$ & $\mathrm{X}$ \\
\hline WOMEN & & \\
\hline
\end{tabular}

For women, family status was the primary determinant of homelessness (See Table 1). Women who lived outside of the patriarchal family were not only socially ostracized and considered homeless because of their non-traditional living arrangements, but they were also more likely to live in poverty. Although women worked in the early twentieth century, female wages were not high enough to support oneself on. Even working women were primarily connected to the labor market through the men they lived with. The absence of a father's, husband's, brother's or 
other male relative's wage plunged women into poverty and put them at risk of becoming homeless.

Recognizing family status as the primary determinant of female homelessness during the early twentieth century was essential for the resolution of this research project. The research process began with an identification of the social service agencies that housed women in Portland from 1900-1929. The rationale for collecting this data was that although for many of these agencies, providing housing to women was not their primary mission, the women they sheltered could not have found other housing options without their intervention. ${ }^{37}$ From the initial analysis of this data the three groups of homeless women emerged: single working women living independently, prostitutes, and single mothers. The data collection process then switched from concentrating on social services to identifying living conditions and discovering the population characteristics of each category of homeless women. ${ }^{38}$ In order to uncover the voices and experiences of homeless women from the existing data which was written by early twentieth century reformers and charity workers, it was essential to examine the relationships that existed between homeless women and their middle class advocates. ${ }^{39}$

The study findings indicate that three groups of women were associated with homelessness in early twentieth century Portland. These three groups included single working women, prostitutes, and unmarried, widowed or divorced mothers. Single working women who lived adrift, or apart from their family, were most commonly associated with homelessness and were the target of an organized reform movement. 
Prostitutes shared the same geographic space and social stigmatization that homeless men encountered. Prostitutes were often portrayed as "unworthy" homeless women. Widowed, divorced, abandoned, or unmarried mothers' economic situation led them to suffer bouts of literal homelessness and family break-up. Within this population of single mothers, there were divisions between the "deserving" poor, such as widows, and the "undeserving" unmarried mother.

In the early twentieth century, single working women living adrift best fit that era's definition of who made up the female homeless population. While women adrift migrated to cities in search of work and when arriving suffered the same low wages, seasonal labor fluctuations and poor housing conditions that homeless men endured, these young single women were not as completely socially ostracized as the male tramping population was. One reason may have been that these women were more settled than their male counterparts. Additionally, for women, living adrift was seen as a temporary phenomenon that was to be tolerated until marriage. ${ }^{40}$ Conversely, transient men were seen as responsible for their condition and many attributed their migratory lifestyle to wanderlust, a preference for idleness, or individual depravity. The services and charities that existed to meet the needs of homeless men were obsessed with separating the "worthy" unemployed from the "unworthy" paupers or bums. ${ }^{41}$

Services for homeless women at this time focused on protecting and preventing them from falling into a life of prostitution. ${ }^{42}$ The prostitute was often equated with the homeless male as a threat to traditional morality and social stability. Many 
prostitutes lived and worked in the neighborhoods that transient males frequented and the same laws were used to persecute both populations. The prostitute was considered the female equivalent of a bum or idle male pauper. She was the epitome of an unworthy charity case, but the ideology of female dependency allowed for her rescue and reform at the hands of politically motivated middle class reformers.

If the prostitute was considered the unworthy female poor, then the widowed mother was the perfect portrait of the deserving case. However, single mothers had the most to lose because of their homelessness. Many suffered family break-up or were forced to give up their children because of low women's wages and the lack of a social safety net. The establishment of a mother's pension program created distinctions between "worthy" widowed single mothers and their "unworthy" unmarried counterparts who were only eligible for restrictive indoor relief.

This study explores the population characteristics and living conditions of these three groups of homeless women. It also traces the development of social welfare policies designed to alleviate the worst aspects of female poverty and the impacts these reforms had on homeless women. The next chapter presents a portrait of life during the early 1900s in Portland. It includes a brief review of the major political and economic milestones for the city, a depiction of the living conditions of the poor at that time and an account of the social services that were available to relieve poverty. The following chapter examines the experiences of single working women and the reform movements that emerged to improve their housing and labor conditions. The fourth chapter focuses on the lives of prostitutes and their relationship 
with the homeless male community. It chronicles the anti-vice campaigns of the 1910 s and 1920s and the effects these movements had on women's civil rights and housing options. The fifth chapter explores the options single mothers had during the early twentieth century and relates the history of the development of mother's pensions, an early social welfare program. It also discusses the emergence of maternity homes for unmarried mothers and the experiences of older, homeless women. The conclusion examines the themes present in the feminine history of homelessness and evaluates the relevance of these ideas to our current situation.

' John Steinbeck, The Grapes of Wrath (New York: Penguin Books, 1939), 419.

${ }^{2}$ Kenneth Kusmer, Down and Out and On the Road: The Homeless in American History (New York: Oxford University Press, 2002).

${ }^{3}$ For the history of homelessness see Kusmer, Down and Out and On the Road; Peter Rossi, Down and Out in America: The Origins of Homelessness (Chicago: University of Chicago Press, 1989); or Henry L. Miller, On the Fringe: The Dispossessed in America, (Lexington MA: Lexington Books, 1991).

${ }^{4}$ Joanne Meyerowitz, Women Adrift: Independent Wage Earners in Chicago 18801930 (Chicago: University of Chicago Press, 1988).

${ }^{5}$ For research on skid row and its inhabitants see: Nels Anderson, The Hobo:

Sociology of the Homeless Man (Chicago: University of Chicago Press, 1923); Donald J. Bogue, Skid Row in American Cities (Chicago: University of Chicago Press, 1963); or Howard M. Bahr, Skid Row: An Introduction to Disaffiliation (New York: Oxford University Press, 1973).

${ }^{6}$ Daphne Spain, How Women Saved the City (Minneapolis: University of Minnesota Press, 2001).

${ }^{7}$ Rossi, Down and Out in America, 35.

${ }^{8}$ Stephanie Golden, The Women Outside: Meanings and Myths of Homelessness (Berkeley: University of California Press, 1992).

${ }^{9}$ See James D. Wright \& Jennifer A. Lam, "Homelessness and Low Income Housing Supply," Social Policy, (Spring 1987): 48-53; Peter Rossi, Down and Out in America; Joel Blau, The Visible Poor: Homelessness in the United States (New York: Oxford University Press, 1992); Martha R. Burt, Over the Edge: The Growth of Homelessness in the 1980s (New York: Russell Sage Foundation, 1992). 
${ }^{10}$ St Anthony's Foundation, Fact Sheet on Women and Homelessness (San Francisco: St. Anthony's Foundation, 1999).

${ }^{11}$ Joan H. Rollins, Renee N. Saris and Ingrid Johnston-Robeldo, "Low Income Women Speak Out About Housing: A High Stakes Game of Musical Chairs," Journal of Social Issues, 57, 2 (2001): 278.

${ }^{12}$ Randy Abelda and Chris Tilly, Glass Ceilings and Bottomless Pits: Women's Work, Women's Poverty (Boston: South End Press, 1997), 24, 53.

${ }^{13}$ Maxine Harris, Sisters of the Shadow (Norman OK: University of Oklahoma Press, 1991).

${ }^{14}$ Joanne Pasarro, The Unequal Homeless: Men on the Streets, Women in Their Place (New York: Routledge Press, 1996).

${ }^{15}$ Rollins, Saris and Johnston-Robeldo, "Low Income Women," 279.

${ }^{16}$ Golden, The Women Outside, 149-155.

${ }^{17}$ Julia Wardhough, "The Unaccomodated Woman: Home, Homelessness and Identity," Sociological Review (1999) 91-109.

${ }^{18}$ Harris, Sisters of the Shadow, 67.

${ }^{19}$ Ben Reitman, Boxcar Bertha: An Autobiography as Told To Dr. Ben L. Reitman (New York: Amok Press, 1988).

${ }^{20}$ See Rossi, Down and Out in America; Kusmer, Down and Out and On the Road; Miller, On the Fringe; or Eric H. Monkonnen, Walking to Work: Tramps in America, 1790-1935 (Lincoln: University of Nebraska Press, 1984).

${ }^{21}$ Douglas Lamar Jones, "The Strolling Poor: Transiency In $18^{\text {th }}$ Century Massachusetts," ed. Eric H. Monkkonen, Walking to Work, (Lincoln University of Nebraska Press, 1984), 21-55.

${ }^{22}$ Miller, On the Fringe, 156.

${ }^{23}$ Monkkonen, Walking to Work, 8, 15.

${ }^{24}$ Kenneth Allsop, Hard Travelin': The Hobo and His History (London: Hadden and Stroughton, 1967), 425.

${ }^{25}$ For early research into skid row and homeless men see: Anderson, The Hobo; Bogue, Skid Row; or Anne Solenberger, One Thousand Homeless Men (New York: Russell Sage Foundation: 1911). For a discussion of the new homeless versus the old see Burt, Over the Edge; Rossi, Down and Out in America; or Wright and Lam, "Homelessness and Low-Income Housing."

${ }^{26}$ Kusmer, Down and Out and On the Road, 110.

${ }^{27}$ See Thompson, Golden, Kusmer, Down and Out and On the Road; or Lynn Weiner, "Women Transients and Tramps," ed. Eric H. Monkkonen, Walking to Work (Lincoln: University of Nebraska Press, 1989), 171-188.

${ }^{28}$ Daphne Spain, How Women Saved the City (Minneapolis: University of Minnesota Press, 2001).

${ }^{29}$ Golden, The Women Outside, 5.

${ }^{30}$ Anderson, The Hobo, 68.

${ }^{31} \mathrm{lbid}, 75$.

${ }^{32}$ Solenberger, One Thousand Homeless Men, 3-10. 
${ }^{33}$ Bogue, Skid Row, 82.

${ }^{34}$ Bahr, Skid Row, 16.

${ }^{35}$ Leonard U. Blumberg, Thomas E Shipley Jr. and Joseph O. Moor Jr., quoted in Bahr, Skid Row, 33.

${ }^{36}$ Solenberger, One Thousand Homeless Men, 3.

${ }^{37}$ Primary data sources used to identify social services agencies include: Multnomah County Archives Public Welfare Records, City of Portland Stanley Parr Archives and Records Center Mayoral Subject Files, Mayoral Correspondence; Portland City Board of Charities Annual Reports, and U.S. Census of Benevolent Institutions 1904 and 1910; secondary sources include: The Oregonian 1900-1929 and The Oregon Journal 1900-1929.

${ }^{38}$ Primary sources include: City of Portland Stanley Parr Archives and Records Center Mayor's Messages and Municipal Reports and Mayoral Official Correspondence, The Vice Commission of Portland Reports I-IV, The Consumer's League of Oregon's Report of the Social Survey Committee of the Consumer's League of Oregon on the Wages, Hours and Conditions of Work and Standard of Living of Women Wage earners in Oregon with Special Reference to Portland; secondary sources include: The Oregonian 1990-1929, The Oregon Journal 1900-1929 and numerous books and articles.

${ }^{39}$ Primary data sources include: Multnomah County Archives, Poor Farm Correspondence and Records and Reports; University of Oregon, Special Collections, Oregon Collection, Board Meeting Minutes of the Portland Florence Crittenton Home; and City of Portland Stanley Parr Archives and Records Center, Mayor's Official Correspondence; secondary sources include: The Oregonian 1990-1929, The Oregon Journal 1900-1929 and numerous books and articles.

${ }^{40}$ Weiner, "Women Transients and Tramps," 45.

${ }^{41}$ Solenberger, One Thousand Homeless Men, 10.

${ }^{42}$ Spain, How Women Saved the City, 92. 


\section{CHAPTER II \\ DOWN AND OUT IN THE CITY OF ROSES: THE LIFE OF PORTLAND'S POOR, 1900-1929}

The dawn of the twentieth century was an era of unprecedented economic and population growth for the city of Portland. The year 1901 was considered "the greatest year for business in the history of Portland."1 The population surged between 1903-1907, growing by $80 \%$. Businesses boomed and Portland soon became the fifth largest wheat exporter in the nation. City government's lack of a business tax and regulation meant that despite large scale economic growth, the city lagged behind in civic amenities like libraries and lacked public services such as meat inspection, garbage collection and street cleaning. Despite these problems, the years before World War I were considered the social heyday of Portland's elites.

By 1910 , a few of those same elites and large numbers of middle and working class Portlanders were disillusioned with business as usual. During the second decade of the twentieth century, Portland cleaned up its image as a "wideopen town" through a civic improvement campaign and a vice crackdown. ${ }^{2}$ In 1913, city hall was reformed and a commission style government replaced the old political machine. The city continued to grow and a real estate boom of single family homes on the east side of the Willamette River changed the architecture and the tenure of many urban residents.

The U.S. entrance into World War I led to an increase in local manufacturing and a housing shortage. ${ }^{3}$ Concerns about the condition and 
affordability of housing for workers eventually resulted in the adoption of a city housing code and the mass construction of single family homes. The war also exacerbated racism in the city and provided a convenient façade for a crackdown on labor organizations and radicals. The wartime economic boom and racial persecution continued well into the $1920 \mathrm{~s}$. By that time, the mass production of the automobile enabled the rapid suburbanization of the east side. Although there were bumps along the way, it was not until the Great Depression hit in 1929 that Portland really stumbled from its upward climb to prosperity.

\section{The Other Side of the Story}

Historian, Joseph Gaston commented in 1910 that inequalities of wealth characterized Portland and that "direct poverty" existed "alongside of single fortunes of $\$ 200$ million accumulated in just forty years." ${ }^{4}$ The economic boom of the early years of the twentieth century was in part created by the labors of tens of thousands of mostly male migratory workers as well as the local laboring classes whose experience of the first years of the new century was far from a social heyday. At the turn of the century, Portland ranked fourth nationally, behind only New York, Chicago and San Francisco, in the raw number of cheap lodging houses that laboring men, women and sometimes families lived in. ${ }^{5}$ By 1911 , Portland charities provided over 31,569 lodgings to men, women and children in temporary shelters, making the city third in the nation in the numbers in temporary lodgings. ${ }^{6}$

One reason Portland had such high numbers of transient, destitute workers was the high demand for seasonal, casual laborers in the resource rich hinterlands 
beyond the city. The forests and farms prospered at the hands of migrant laborers who planted the fields, harvested crops, cut timber, and worked the mines. Thousands of mostly single men crisscrossed the country performing this labor necessary for opening the frontier. ${ }^{7}$ They were poorly paid and although employment was abundant during the summers, many men flocked to the city where they spent the winter, unemployed. A community grew up in the downtown neighborhoods near the train station and wharfs that unemployed men frequented. Sawyer identifies the years from 1908 to 1917 as the ascendancy and pinnacle of Portland's skid row. ${ }^{8}$

Skid row in Portland was primarily concentrated in the North End of downtown, although a smaller lodging house district also emerged in the immigrant working class neighborhoods of South Portland. The abundance of cheap lodgings from comfortable hotels to barely habitable flophouses, a density of low-cost restaurants, secondhand stores, homeless male missions, saloons and burlesque houses and employment agencies characterized skid row neighborhoods. ${ }^{9}$ The North End and other skid rows across the nation were noted for their high male to female ratios and comparative lack of children. In 1910, the wards that made up Portland's skid row were from $65 \%$ to $78 \%$ male. $^{10}$

Living conditions in Skid Row were poor. In 1910, the Portland Women's Club visited over forty lodging houses in Portland. ${ }^{11}$ Among the conditions they found were board slabs for bunks, infested bedding, no ventilation, and overcrowding. In another building, one big room were partitioned off into sleeping 
cubicles that had ceilings made of cheesecloth. ${ }^{12}$ Sixty-five cubicles like this on each floor shared one toilet and two sinks. Despite the poor housing conditions of skid row, the men and women who lived there formed a distinct community and culture. In Portland, unemployed men organized into unions, opened and ran a self-managed shelter and free food program and even had a branch of the national hobo college. ${ }^{13}$

Sawyer identifies the World War I era as the beginning of the end of Portland's skid row. ${ }^{14}$ Not only did the draft transfer some men from the army of the unemployed to the front lines of the European war, but also the war effort at home created a steady supply of year-round urban work opportunities. Housing codes were enacted in 1920 that restricted and licensed many skid row lodgings, and by then mechanization had reduced the need for manual labor in the farms and forests. By 1929, skid row was a shadow of its former self and the Great Depression drew attention away from destitute single men to the plight of poor women, children, and families.

Families had always comprised a large portion of the resident poor. Unlike the transient male population, the resident poor were geographically dispersed throughout the city and they did not form a coherent community, which makes it difficult to estimate their numbers. The low wages and seasonal nature of work that impoverished single men also led many families to destitution. In addition, injury, disability, or death of a male breadwinner could change a family's fortune overnight. Families survived the brutal conditions of the labor market and relative 
lack of a social safety net by relying on each other, extended family and their immediate community. If the male breadwinner was unable to work or earn enough money to support his household, other family members, including the children, would go to work. Sometimes extended family would help out and Katz stresses the importance of credit extended by local merchants as a survival mechanism for the poor. ${ }^{15}$ Just as single men moved on in search of work, many families became transient. Only one third of households remained in the same city for more than ten years.

Not many families were found living in the cubicle hotels or flophouses frequented by single unemployed men. However, families also suffered substandard housing conditions that included a lack of ventilation, insufficient water and waste disposal systems, and overcrowding. In 1905, in South Portland, six families were crowded into a small house, which they shared with a cow. ${ }^{16}$ In 1919 , an Italian family with six kids lived with four lodgers in a four-room house. 17 Three families shared a two-room apartment in a rooming house; they used one room to cook and eat in and the other to sleep. Another rooming house crowded in eight families who all shared a single hall sink. Over half of the families in lodging houses did not have water in their rooms and had to share a bathroom with other tenants. One survey of downtown rooming houses found $60 \%$ of toilets dirty and $31 \%$ filthy. One third of families did not have access to a bathtub, only a coldwater tap. 
In addition to poor housing conditions many destitute urban families also suffered from hunger. During the first decade of the twentieth century, the Salvation Army and Volunteers of America consistently fed at least 2,000 family members each Christmas. $^{18}$ In 1921, a Health Department examination of Portland public school children discovered $25 \%$ of them underweight and malnourished. ${ }^{19}$

\section{Charities, Social Services and the Politics of Relief}

At the turn of the twentieth century, there was no public relief available to workers who were laid off, injured on the job, disabled, or too old to be productive laborers. If family and the community could not support them, the poor were forced to beg from strangers in the streets or at the local charity office. No federal programs existed to help the elderly disabled, destitute children or the down on their luck. County governments had the responsibility for allocating tax money in the form of limited relief.

In 1851, the Multnomah County Commissioners recognized the provision of poor relief as one of their governmental responsibilities. ${ }^{20}$ The offered outdoor relief, or small sums of money, to the poor who could show they had been residents of the county for at least twelve months. Non-residents were sent back to their county of origin empty handed. Before the county court would offer relief, an effort was made to track down family members who could provide care. The court first tried to locate parents or children of the relief applicant and if none could be found, brothers and sisters were the next responsible kin. 
In 1854 , the county court established an alternative, indoor relief, or institutions to care for paupers. ${ }^{21}$ Adults could be sent to the newly established poorhouse, which was completed in 1868. Children whose parents could not afford to provide for them were indentured out as apprentices in private homes. Prior to the 1870 s, most charity work had been driven by religion or to a lesser extent, philanthropy. By the late 1870s a new form of type of aid organization emerged. The Charity Organization Society was a national movement that sought to separate religion from social service work, and pioneered an ideology of "scientific charity." ${ }^{, 22}$ One of the primary aims of the scientific charity movement was to abolish outdoor relief.

Scientific charity differed from its alms-giving predecessors in three ways. First it did not link the provision of charity with religious conversion or persuasion. ${ }^{23}$ The second difference was the Charity Organization Societies were not organized to distribute relief; they merely screened applicants and coordinated the efforts among different agencies. Finally, scientific charity was business-like and involved the use of "friendly visitors" to evaluate the worthiness of the potential recipient in a systematic manner. Scientific charity emerged under a political context of increasing urban working class militancy. So the "task charity organizations set themselves was to teach the poor that they had no rights. Afraid relief was turning into a right, the new reformers put all their energy into transforming it back into charity.,24 
Although a branch of the national Charity Organization Society did not exist in Portland, the City Board of Charities, organized in 1888, practiced scientific charity and was affiliated with the national C.O.S. movement. The City Board of Charities did not distribute relief; instead its mission was "to investigate thoroughly and without charge the case of all applicants for relief... and to provide friendly visitors." ${ }^{25}$ After a complete investigation, the organization would solicit relief for "deserving" cases, locate work for the able bodied male poor or "expose" imposters. The City Board of Charities also worked with other agencies to "suppress and punish vagrancy and vagabondage." In its first year of operation, the City Board of Charities investigated 1135 cases.

In 1899 , the City Board of Charities began a campaign to end all outdoor relief in Multnomah County. ${ }^{26}$ When they did not succeed, they instead tried to get the county to refer all relief applicants to their organization for investigation. In 1900 , the county agreed to refer a portion of its cases to the City Board of Charities, but Multnomah County maintained its own relief worker. Outdoor relief continued to be distributed and allocations for it roughly equaled the expenditures of the poor farm.

County relief payments and private charities did not help all of the poor. Many families and individuals were instead helped by numerous mutual aid societies that existed. Ethnic and religious organizations helped their members that needed temporary assistance. ${ }^{27}$ The Danish Aid Society, the Giuseppe Society, the German Relief Society, and the British Relief Society provided help to the needy in 
specific ethnic populations in Portland. The Saint Ann's Society and the Saint Vincent de Paul Society assisted Catholics who were in need of relief. Chinese men relied upon benevolent associations for economic and social support. African American Portlanders rarely received assistance from white charities or county relief so they too organized in fraternal associations that provided social activities and mutual aid. ${ }^{28}$ Some black fraternal organizations included: the Enterprise lodge, the Dahlia Temple, and Rose City Lodge. These organizations were literally lifesavers for many blacks in Portland, because female members rotated duties nursing the ill, because blacks were denied access to hospitals.

By the 1910 s, scientific charity was beginning to be replaced by a social work approach, which utilized social scientific methods and employed apolitical caseworkers. Early social work was deeply influenced by the new field of psychology. "As the impersonal case worker replaced the friendly visitor, social workers joined other contemporary experts who tried to teach people to adjust to their environment not change it." ${ }^{29}$ In Portland, the first transformation to a case management approach began in 1911 as the City Board of Charities reorganized into the Associated Charities and set up a committee to look into the adoption of social work practice. ${ }^{30}$ By World War I, the organization had embraced case management. In 1918, Multnomah County implemented the Public Welfare Board, which used trained social workers. Many of those caseworkers were recruited from the University of Oregon's new school of social work. 
By the 1920s, relief looked much different than it did at the turn of the century. College educated caseworkers replaced the friendly visitor and the county no longer referred able-bodied relief applicants to the dreaded poor farm. The beginnings of the modern welfare state were in place, including old age and mother's pensions, which were predecessors of social security and aid to dependent children programs. A state worker's compensation program was implemented, as were labor laws regulating hours and wages for some workers and prohibiting child labor. Katz attributes the emergence of a social safety net and the establishment of other publicly funded institutions like schools and hospitals to increased worker productivity and efficiency, which necessitated the creation of retirement and disability. ${ }^{31}$ As workers and mechanization made firms more productive, capitalism had to find a way to dispose of surplus labor. The elderly and the young could be taken out of the workforce.

Many historians proclaim the late 1920 s to be the beginning of the death of skid row. ${ }^{32}$ The culture and community within the neighborhood were dramatically changed by the persecution of radical labor organizations that occurred during World War I. The 1919 general strikes in Seattle and Tacoma terrified local authorities and set out to destroy what was left of the local I.W.W. and other radical unions. During the 1910s life had improved for the transient male worker. Labor and social welfare legislation increased economic security which led to the decline of penal institutions for the poor. By the 1920 s social welfare remained stagnant and imprisonment and harsh punishment of the unemployed was again on the rise. 
The single homeless male would soon disappear from the public eye as thousands of families lost their homes in the Great Depression. What appeared to be incremental improvements in the social welfare system in the first three decades of the twentieth century would seem miniscule in light of the need during the 1930s. While public and private relief organizations became more professionalized and the state began to take some responsibility for the welfare of its poorest citizens, poverty continued to plague the nation and the many of the poor continued to be deemed 'unworthy' of services.

${ }^{1}$ E. Kimbark Mac Coll, The Shaping of a City: Business and Politics in Portland OR 1885-1915 (Portland: The Georgian Press, 1976), 225, 23, 287, 314.

${ }^{2}$ Carl Abbott, Portland: Gateway to the Northwest (Tarzana CA: American Historical Press, 1997), 88-95.

${ }^{3}$ Ibid, 97-99, 105.

${ }^{4}$ Joseph Gaston, Portland: It's History and Its Builders (Chicago: S.J. Clarke Co., 1911).

${ }^{5}$ Chris D. Sawyer, "From Whitechapel to Old Town: The Life and Death of the Skid Row District in Portland Oregon" (Ph.D. dissertation, Portland State University, 1985), 253.

${ }^{6}$ U.S. Bureau of the Census, Census of Benevolent Institutions, 1911, 15, 44-45.

${ }^{7}$ Henry Miller, On the Fringe: The Dispossessed in America (Lexington MA:

Lexington Books, 1991), 37.

${ }^{8}$ Sawyer, "From Whitechapel to Old Town,"268.

${ }^{9}$ Ibid, 82.

${ }^{10}$ U.S. Bureau of the Census, $13^{\text {th }}$ Census of the United States, 1910, Supplement for Oregon. Table V: Compositions and Characteristics of Population for Wards of Portland.

${ }^{11}$ City of Portland, Stanley Parr Archives and Records Center, Mayor (Archival), Subject Files, A2000-003, 7/34, 1910.

${ }^{12}$ City of Portland, Stanley Parr Archives and Records Center, Housing, Cheney Reports, 1919, 5000-02, 7/6, 1919, 19.

${ }^{13}$ Sawyer, "From Whitechapel to Old Town," 237, 279.

${ }^{14} \mathrm{Ibid}, 270$.

${ }^{15}$ Michael B. Katz, In the Shadow of the Poorhouse: A Social History of Welfare in America (Basic Books: New York, 1996) 5, 9.

16 "All in One House," Oregonian, 16 April 1905, p. 6. 
${ }^{17}$ Cheney Reports, 16, 17, 19.

18 "Many Hungry Ones Fed by Charity," Oregon Journal, 25 December 1904, p. 2; "More Poor People in Portland," Oregon Journal, 25 December 1916, p.1; "Day of Days Brings Joy," Oregon Journal, 24 December 1907, p.2.

${ }^{19}$ City of Portland, Stanley Parr Archives and Records Center, Mayor's Messages and Municipal Reports, 1921, 362.

${ }^{20}$ Amelia Ann Feary, "The Origins and Development of Family Social Work in Portland Oregon" (Master's Thesis, University of Oregon, 1936), 126.

${ }^{21}$ Federal Works Progress Agency, Inventory of County Archives of Multnomah County Oregon, Volume I OR Historical Records Survey, (Portland OR 1940), 169.

${ }^{22} \mathrm{Kat}$, In the Shadow of the Poorhouse, 60.

${ }^{23}$ Ibid, 60 .

${ }^{24}$ Ibid, 78.

${ }^{25}$ Feary, "The Origins and Development of Family Social Work,"167.

${ }^{26}$ Ibid, 133, 181-2.

${ }^{27}$ Feary, "The Origins and Development of Family Social Work," 119.

${ }^{28}$ Elizabeth MacLagan, A Peculiar Paradise: A History of Blacks in Oregon 17881940 (Portland: The Georgian Press, 1980), 119.

${ }^{29} \mathrm{Katz}$, In the Shadow of the Poorhouse, 171.

${ }^{30}$ Feary, "The Origins and Development of Family Social Work," $187,191,193$.

${ }^{31} \mathrm{Katz}$, In the Shadow of the Poorhouse, 187.

${ }^{32}$ Sawyer, "From Whitechapel to Old Town," 270, 323, 346. 


\section{CHAPTER III \\ WOMEN ADRIFT: WAGE EARNING WOMEN ON THEIR OWN}

The twentieth century was a time of change in women's work and labor force participation. In $1900,20 \%$ of all women in the U.S. labored outside the home, making up $18 \%$ of the total labor force. ${ }^{1}$ The highest rate of employment among any group was young single women. Forty percent of unwed daughters over age fourteen earned a wage. In Portland, $23.4 \%$ of women over the age of ten worked in $1900 .^{2}$

Unlike their earlier counterparts, twentieth century women workers did not all live at home or reside in company dormitories or the households where they were employed. One fifth of women wage earners in 1900 lived independently. ${ }^{3}$ These women workers living apart from their families were viewed as 'homeless women' or 'women adrift'. Women were characterized as 'adrift', or lost, because they lived outside of traditional family structures. The term 'homeless women' applied to female boarders, and lodgers, as well as destitute women who slept outdoors or in the police station. ${ }^{4}$ According to a 1913 Consumers League of Oregon report the term woman adrift is "meant to cover all cases of a girl practically without a home. Those who are living in rooming and boarding houses and entirely dependent upon their own wages are without question adrift."5

Women began living adrift as more occupations became open to them. Prior to the late nineteenth century most working women had labored as domestics and received room and board as part of their compensation. ${ }^{6}$ By 1900 , new fields opened to women. Female sales help replaced male clerks in department stores and clerical 
work became increasingly feminized in the early twentieth century. In 1900 women comprised one third of the clerical labor force, by 1920 they made up half. ${ }^{7}$ Slowly the prototypical female worker was changing from a live in servant to an urban wage earner.

According to Lynn Weiner, the phenomenon of women living independently was not only a result of urbanization and the subsequent expansion of economic opportunities for women in cities, but it was also affected by the concurrent lack of wage earning prospects for single rural women. Single women migrated to work in cities at greater rates and at a younger age than their rural male counterparts. ${ }^{8}$ Women's migration peaked at age eighteen while many men did not leave home until age twenty. Some rural women who moved to the city found housing with friends or family, but others boarded or lodged with private families or rented rooms in commercial lodging houses.

Although in 1912, one third of the urban female workforce lived adrift, employers continued to pay women wages that were too low to pay for their basic necessities. ${ }^{9}$ Employers assumed that women lived at home and claimed they only worked for pin money. Throughout the twentieth century women have earned less than men, even for the same work. In 1911, male bakers in Portland made three dollars a day while women only earned seven dollars a week. ${ }^{10}$ Women's wages were also depressed through occupational segregation. Traditionally male occupations paid better than those jobs available to women. In 1911, Portland bricklayers earned five dollars a day while seamstresses took home three dollars a day. Despite the 
employers' claims that women worked for fun, in 1913, Harriet G. a twenty four year old woman with ten years of work experience in Portland commented, "I did not know of any girl who worked that didn't have to."11

\section{Women's Work and Wages}

The Consumer League's 1912 survey of 7036 women wage earners in the city of Portland found that that women's earnings were "miserably inadequate to meet the cost of living at the lowest standards consistent with the maintenance of the health and morals of the workers." ${ }^{, 12}$ Three fifths of the Portland women surveyed earned less than ten dollars a week. Just one year after the Consumer League published their findings, the Washington State legislature determined that women needed to earn between $\$ 9.81$ and $\$ 10.29$ a week just to survive in the Pacific Northwest. ${ }^{13}$

Three quarters of female factory workers in Portland earned less than ten dollars a week in $1912 .{ }^{14}$ One third of these women workers earned less than seven dollars a week and half made less than eight dollars for a sixty-hour week. Women worked ten-hour days with just one unpaid hour-long lunch break. Many factories did not have heat and the work was monotonous. In one candy factory, chocolate dippers spent their entire day rolling bits of cream in chocolate or making a swirl pattern on the top of a bon-bon. After ten hours of this work, the chocolate stained their hands and no matter how well they washed the workers could not get rid of the smell of the candy. ${ }^{15}$ 
Female factory workers not only worked long hours and were poorly compensated, they were also subject to frequent layoffs. One shirt factory seamstress noted in 1911 that her shop hired 400 workers during the busy season but only 200 remained in off times. ${ }^{6}$ According to the 1900 census, 301 of 1633 female manufacturing workers were laid off from one to twelve months that year, most averaging three to four months without work. ${ }^{16}$

The factories with the worst wages and poorest working conditions were fruit and vegetable processing plants. In canneries, women and girls earned the piece rate immediately and usually averaged from three to five dollars a week. ${ }^{17}$ They worked twelve to sixteen hour days. It was not uncommon for children as young as eleven years old to be working beside their mothers in the summertime. The canneries opened at 6 a.m. and during the height of the season did not close until 10:30 p.m. "Children aged twelve to thirteen have been seen crying because they were too tired to work" after managers locked workers in the plant at 6 p.m. ${ }^{18}$

One woman who had worked in a fruit packing plant for eighteen years earned only eighty cents a day and considered it the "worst place in the city of Portland for a girl to work". ${ }^{19}$ Fruit and vegetable processing work was highly seasonal most women suffered periods of unemployment. ${ }^{20}$ Many of the mothers worked in the fruit processing plants and canneries during the summer did domestic day work in the winter.

Despite the commercial laundries' reputation as good places to work, this industry was also characterized by low wages and difficult working conditions. In the 
Consumer League's report, 130 out of 140 laundry workers that were interviewed earned less than ten dollars a week. ${ }^{21}$ Women earned a minimum wage of $\$ 1.25$ a day and up to a maximum of two dollars daily. Laundry facilities were hot and poorly ventilated. However, commercial laundry work, along with other forms of domestic work was of the few employment opportunities open to non-white and immigrant women. Although the category included washerwomen in private homes in addition to employees in commercial facilities, at least half of the laundresses in the 1900 and 1910 census data for Portland were either immigrants, black or Asian. ${ }^{22}$

There was a perception that women in commercial laundries were "tougher" girls, who used coarse language. ${ }^{23}$ Commercial laundresses, like other working women, were often forced to supplement their income through some form of prostitution. Laundry workers used "hook "em" notes to try and secure dates with male customers. The women would pin a note to men's underwear or shirts. These notes contained workers phone numbers or addresses and a line to "hook" their customer such as "call me up I'm a live one" or " answer if not married."

Laundresses working in private homes faced different employment challenges. They were part of the army of servants that were required to run middle or upper class homes in the early twentieth century. Prior to the Civil War, most women were limited to domestic employment or agriculture. Donald Sutherland contends that after slavery ended and Europeans emigrated in large numbers, domestic service became regarded as menial work that was highly stigmatized because of its associations with blacks and recent immigrants. ${ }^{24}$ In 1915 , one servant called domestic work a "form of 
semi-slavery" and wondered "who of us would join the ranks of servants if it were possible to do anything else for a living?,25

For many women, domestic service was the only option. For black, Asian or Native American women, domestic work was one of the few urban employment opportunities open to them. In 1900, $85 \%$ of non-white women workers in Portland were employed in the domestic trades. ${ }^{26}$ Immigrant women were also over represented in household employment. In 1900,64\% of immigrant women worked in private households. Despite the multiracial make-up of the domestic workforce, employers never hired an integrated staff. Some households had an all black domestic workforce while others only hired native-born whites or immigrants. Domestic workers as a group tended to be young, single women, however as women aged they found a difficult time getting employment in factories, department stores or as clerks. In $1900,58 \%$ of Portland women workers over the age of 45 worked as domestics.

Part of the stigma attached to domestic work was a result of the long hours and poor conditions servants labored under. In 1900 three quarters of domestic workers labored ten hours a day, often starting their chores at four or five in the morning. ${ }^{27}$ Many domestics lived with their employers and received only one afternoon and one evening off each week. Not until 1917 was it common for servants to have one full day off each week. Pay for the work varied, but when room and board was included, domestic workers were often better fed and housed than their factory and department store counterparts. However "no amount of money, good food or pleasant living 
conditions, even if forthcoming, could compensate for their lost liberty or lowly position." 28

Despite the stigma attached to it, domestic work continued to be promoted as the most socially acceptable form of work for women. Public agencies and private charities endorsed it. The Council of Jewish Women founded The South Portland Industrial School in 1898, which trained young immigrant girls in preparation for domestic work. ${ }^{29}$ The city-run Portland Free Employment Bureau found positions for 920 women in 1915 and sent $92 \%$ of them to various domestic positions. ${ }^{30}$ In 1923 , the Public Employment Bureau placed 2443 women, $50 \%$ of them found permanent jobs, compared to only $25 \%$ of the men. ${ }^{31}$ Domestic jobs were easy to come by but had extremely high rates of turnover. In a U.S. Department of Labor survey of domestic workers conducted in $1924,52.2 \%$ of women had worked at their position for less than one year. ${ }^{32}$ Many domestic workers left because employers made unreasonable demands upon them. Employers often complained that new hires were unwilling to learn, so they preferred to fire servants rather than retrain them.

By the early twentieth century, if a woman did not want to work in a private household she could use her domestic skills in the expanding commercial boarding house, hotel or restaurant industry. Hotel chambermaids were usually responsible for cleaning thirty rooms and a hall. ${ }^{33}$ They were paid six dollars a week and given a room in the hotel. Waitresses earned between six and eight dollars a week and had access to free meals. They either worked the day shift from 6 a.m. to 4 p.m. or the night shift from 4 p.m. to midnight. 
Unlike the multiethnic and multiracial make-up of the female domestic workforce, department store workers and other sales positions were primarily filled by white, native-born women. In 1910, of Portland's 1223 saleswomen, only two were not white ${ }^{34}$ Sales positions accounted for just $2 \%$ of employment among the female immigrant labor force. Despite the profession's domination by traditionally higher valued white native-born women, wages and working conditions in sales positions were not that much different than their factory worker counterparts.

Department store workers in Portland received a starting wage of only three dollars a week and the average clerk was paid six dollars. ${ }^{35}$ After nine years at the same store, one woman was able to raise her wage to thirteen dollars a week. However, advancement and raises were not guaranteed. Women could be fired if they did not sell enough merchandise, although they were rarely promoted if they made extra sales. The purpose of a sales woman, unlike her male counterpart, which had dominated the industry until the late nineteenth century, was, "not to urge the customer to buy...they simply ask the customer what he or she wants and make a record of the sale." ${ }^{, 36}$

Department store clerks worked an eight and a half hour day with a forty-five minute lunch break. ${ }^{37}$ Women stood their entire shift and in some stores even the lunchroom did not have benches. ${ }^{38}$ Department store clerks were denied bathroom breaks and were made to stand still at their counters. The women dressed in shirtwaist dresses that they provided, kept clean and mended when necessary. Department store work was seasonal and sales clerks were expected to work overtime for the Christmas 
and Easter rushes. One woman remembered taking morphine with her co-workers to "dull the long hours of standing" during a Portland department store's Christmas rush. ${ }^{39}$ After the busy season was over, many women were laid off. Although the work was tedious, poorly compensated and often temporary, department stores kept long waiting lists of women who hoped to be hired.

In addition to poor pay and difficult working conditions, many women also had to contend with sexual harassment. While it was not uncommon for domestics to experience unwanted advances by their male employers, sexual harassment was rampant throughout department stores. Bosses encouraged the practice of "treating" or buying women gifts and taking them out in exchange for sexual favors. ${ }^{40}$ Sometimes male clients who frequented the store solicited women for a "treat." One department store worker who complained about her low wages was told, "That's why you have your evenings off.",

In smaller stores a woman's appearance was not as much a factor as it was in the hiring of their department store or 'shoppie' counterparts. Sales clerks at Woolworth's and other five and dime stores earned lower wages and worked longer hours. Young girls started at four dollars a week. The maximum wage a woman could earn at Woolworth's was six dollars a week. One woman adrift commented, "my salary is so small I have to work for room and board after working ten hours at the store." ${ }^{42}$

Just as the department stores feminized their workforce at the end of the nineteenth century, the clerical labor force dramatically increased its hiring of female 
workers in the early twentieth century. In 1900 , clerical work accounted for only $4 \%$ of the total female employment in Portland, by 1910 it had grown to $11 \%$ and by 1920 it increased to $16 \%{ }^{43}$ Clerical positions, like sales work were restricted to white women. Immigrant women fared better in the office trades than in department stores and clerical positions accounted for $7 \%$ of foreign-born women's employment in 1910, however black women were virtually absent from the field.

Half of all office workers made less than ten dollars a week. ${ }^{44}$ The starting wage for clerical help was five dollars a week. Skilled workers, such as stenographers or bookkeepers earned higher wages. Over three quarters of all stenographers made more than ten dollars an week. Most clerical workers labored nine to ten hours a day and were not as affected by economic cycles as their factory counterparts.

The printing trades were one of the few unionized positions open to women in Portland. One of the most coveted trades was bookbinding. Many female bookbinders who worked until they married would often return to the trade later. Bookbinders worked an eight hour day and received time and a half pay for overtime. ${ }^{45}$ While unionization resulted in better working conditions for women it did not translate into equivalent pay with men or even a livable wage for female workers. Women apprenticed at six dollars a week and advanced to six fifty after six months. Within two years women earned eight dollars a week.

Around the turn of the century, the rapidly expanding telephone and telegraph industry increased its use of female labor especially as telephone operators. The industry claimed women's voices were "more calming" but the true motivation for 
hiring women was that they could be paid substantially less than their male counterparts. ${ }^{46}$ Telephone company apprentices started at one dollar a day. After a two month training period, wages rose a dime. Half of all female workers made less than ten dollars a week. Unlike most other jobs open to women, telephone operators labored under decent conditions. They worked an eight hour day and received a fifteen minute break every two hours. The telephone company provided a lunchroom that served warm meals at cost to their workers. ${ }^{47}$

\section{Living Conditions for Women Adrift}

In $191225 \%$ to $35 \%$ of the female workforce in Portland lived adrift. ${ }^{48}$ With the low wages they earned and hours they worked most women crowded into small, comfortless rooms, ate only once or twice a day, and relied upon their talents to create a social life. Women adrift either lodged or boarded with a family or lived in a commercial rooming house. Lodgers rented a room to sleep in and boarders received meals in addition to a room. By the twentieth century, one third to one half of U.S. residents had either lodged or boarded with a family or had taken in boarders or lodgers at some point in their lives. ${ }^{49}$ Most families took in two boarders at a time. Some ran small commercial boarding houses with six to ten tenants. For poor families, boarders were often their only reliable source of income. In 1919, one Portland single mother and her two children lived and slept in one windowless room of their four room house in order to rent the other three rooms out to ten lodgers. ${ }^{50}$

Paul Groth links the decline of the practice of boarding with families with the rise of the commercial rooming house in the early twentieth century. ${ }^{51}$ Rooming 
houses were cheaper to run, since meals were not provided. Commercial rooming houses were often no more than subdivided single family homes that housed 16 to 18 different tenants or families. Large parlors or dining rooms fetched the highest rent and hallways and attics were the cheapest. Most houses had only one bathroom and no central heating. Rooms in subdivided single family homes were often advertised as "furnished rooms." Nationally, one- third to one half the residents in rooming houses were women.

Rooming houses were managed by a live in landlord who locked the door at an appointed time each night. Some landlords converted their furnished rooms into "housekeeping rooms" by adding a gas burner and cookware and charging more for rent. A housekeeping room was merely "one room furnished with a gas plate, an improvised pantry and a 'cooler' in the window with milk bottles and paper bags on the sill, a bed behind a dingy curtain, clothes hung behind the door and a few dishes to complete the equipment. ${ }^{, 52}$

In addition to subdivided single-family homes, rooming houses were carved out of empty warehouses in downtown areas. These converted warehouses were nothing more than rows and rows of sleeping cubicles that often lacked adequate air, light, ventilation and toilet facilities. Large scale commercial rooming houses were more anonymous than furnished rooms and cheaper. They became known as "upstairs hotels." ${ }^{53}$ Soon downtown buildings were not just being converted into lodging houses, but new hotels were constructed in this fashion. These upstairs hotels were located in downtown areas near neighborhoods of subdivided single-family homes that 
became known as rooming house districts. Rooming house districts were not just characterized by cheap housing but also by the high proportion of adults that lived there. Unlike other neighborhoods in the city, relatively few numbers of children lived in rooming house districts.

As early as 1902, Portland had gained the reputation as a city of "homeless people." ${ }^{, 54}$ One article estimated that the numbers of men and women living in hotels, lodging houses and furnished rooms was close to 20,000 . Contrary to the values of the times, men and women often lived in the same rooming house or upstairs hotel, sharing the hall and to the horror of many middle class reformers, even the bathroom. In 1919 a survey of 10,000 sleeping rooms revealed that $45 \%$ rented to men only, $7 \%$ to women only but $48 \%$ took men or women. ${ }^{55}$

With the average women's wage under ten dollars a week, women who lived adrift had a limited choice of affordable lodging. Eight dollars a month could rent a room if the tenant cared for the landlord's children and helped out with household chores. ${ }^{56}$ Ten dollars a month bought an attic room with a stove for heat, but the tenant was required to provide her own wood. She also had to share a single bathroom with the other tenants, which was located downstairs on the back porch. Rooms did not begin to get comfortable until prices reached twelve dollars a month.

Housekeeping rooms often ran as high as sixteen to twenty dollars a month, but with cooking facilities women could save money on food, which many times was as costly as housing. In order to pay for housing, some women took roommates. Joanne Meyerowitz estimates that between 30 to $60 \%$ of women adrift lived with 
roommates. ${ }^{57}$ Roommates allowed women to rent larger, more comfortable rooms, but also left them vulnerable. If a roommate moved out or suddenly lost her job, a woman would have to find someone to replace her or struggle to pay a higher rent. Many more comfortable housing options, such as apartment houses, would not rent to single women, until the 1920 's. One landlord commented, "no single woman, working or not, has ever been presumed trustworthy, economically solid or discreet enough to make a desirable tenant." ${ }^{158}$

Another option for women who wished to save money on food was to find a situation that offered room and board. In 1913 the going rate for a room with board was twenty-five dollars a month, although a cheaper but less desirable situation could be found ${ }^{59}$ Mrs. R, a janitress, paid twenty dollars a month for room and board for herself and her daughter, but living on $\$ 7.50$ a week she still did not have money enough to pay for clothing or the child's school fees. The board some women received was not enough to silence their hunger pains. One woman who had lived adrift in Chicago was fed bread and coffee for breakfast and a bowl of pig snout soup for dinner as her board. ${ }^{60}$ After a ten hour work day, many women longed for a decent meal.

Restaurants and cafeterias became the kitchens and dining rooms for women lodgers. Downtown rooming house districts were home to a variety of different cheap eating options for lodgers. Three for two restaurants offered three ten cent courses for a quarter, or two bits. ${ }^{61}$ Dairy lunchrooms and basement restaurants also provided cheap meals. Many saloons transformed into lunch counters during Prohibition. As 
early as 1902 , Portland was home to 105 restaurants each of which served an estimated one hundred and fifty a day. ${ }^{62}$ Despite the frequency of cheap eating establishments, some women were still too poor to afford to eat properly. For them, skipping meals was a common survival strategy. Miss Z., who worked in a laundry, was too tired to eat after work, but she was grateful because it enabled her to save money.

Although wages were poor, housing conditions substandard and hours were long, many women adrift found creative ways to maintain an active social life. The typical eight dollar a week salary women made barely paid for an "unsatisfactory room and a fair amount of food in unpleasant places." ${ }^{63}$ On such low wages a woman had to wash her own laundry and could not afford newspapers, magazines or a new outfit. One woman believed she suffered more from the loneliness of living adrift than the poverty. She could not afford a YWCA membership and spent much of her free time in the Portland public library. Other women adrift however took part in the new commercialized entertainments that were quickly shaping urban youth culture.

In the early twentieth century, new forms of commercialized amusements were becoming popular urban pastimes and profitable industries. In Portland, Council Crest and the Oaks amusement parks attracted visitors of all ages and bicycle tracks were popular for a period of time. In the North End as well as rooming house districts across the nation, dance halls, cabarets and movie theaters joined the already abundant saloons to form what Meyerowitz refers to as a "bright lights" center where male and female neighborhood lodgers could socialize. ${ }^{64}$ Meyerowitz credits women adrift with 
creating their own "peer-oriented" subcultures with male and female co-workers and friends they met at local establishments. The unsupervised mixing of men and women in the bright lights of the rooming-house districts challenged the middle class Victorian sexual mores of the times.

Some women adrift actively participated in a rooming house subculture that was more accepting of premarital and casual sex, cohabitation and homosexual relationships. Amanda M. lived with her male lover and until her out of town uncle discovered them. ${ }^{65}$ He contacted local Portland authorities and the police began an investigation. Her lover refused to cooperate, but when questioned alone Amanda admitted they had not married. The police gave them a few days to get married. By the next weekend the two officially became husband and wife before a judge in Vancouver, WA. Unmarried couples could be prosecuted for lewd cohabitation under contemporary laws. In 1905, sixty five were arrested for this offense. ${ }^{66}$

While many women chose sexual relationships with men or other women to satisfy their own physical and emotional needs, others sought out lovers for economic reasons. Women who casually picked up men, had a steady sexual relationship with a man or lived with a lover, regardless of their motivations, became known as "charity girls." One charity girl who had worked in shops, factories and as a waitress commented, "the only way a girl can have clothing and the things she wants most in life is to live the life I am living." ${ }^{67}$ Another young woman who made $\$ 6.50$ a week at her department store job went to grills to meet "classy friends." She had traveled 
across the country with a female friend picking up men along the way. She currently had a lover who helped her out twenty dollars at a time.

Despite their exchange of sexual favors for money, most charity girls were not professional prostitutes. These women continued working at their jobs and often lived independently. They chose the men they consorted with and not all charity girls engaged in sexual relationships for purely economic reasons. Joanne Meyerowitz contends the sexual revolution of the flapper era had its roots in the working class youth subcultures that women adrift participated in. "The working class women adrift did not simply reject middle-class patterns, they helped chart the modern sexual terrain. For these women, sexual expression not only promised pleasure; in a variety of forms, it also promised financial reward." ${ }^{, 68}$

\section{Rescuing Homeless Girls and Reforming the Lives of Women Adrift}

Women adrift were both the target of and the impetus behind many middle class women's reform movements. Denied the vote and relegated to the domestic sphere, Sandra Haarsager suggests that the middle class women's club movement became the primary vehicle for female political action. ${ }^{69}$ The club movement had begun as a way for middle class educated women to come together for cultural enrichment and social interaction. By the late nineteenth century, women's clubs in the Pacific Northwest had expanded their missions and activities to include civic, social and political activism. Prior to the twentieth century, one of the first women's clubs to connect domestic issues with political demands was the Women's Christian 
Temperance Union (W.C.T.U.). The W.C.T.U. was a national organization that campaigned for prohibition of alcohol in order to improve the lives of women and children who bore the physical and economic brunt of men's drinking habits.

In addition to the ban of alcohol, the Portland W.C.T.U. expanded their protectionist agenda to include women workers and female newcomers to the city. The Portland W.C.T.U. created a 'noon rest' station downtown where working women could nap on their lunch hours. In 1892, this building became the headquarters of the Working Women's Club, an organization that was created by and for female laborers. In 1896 , the W.C.T.U. paid a matron to meet newly arriving single women at the train station and direct them to boarding houses and employment agencies that were deemed respectable by the club.

In 1905, the first concerted effort to address the needs of transient workingwomen culminated in the establishment of a local Travelers' Aid Association. Although the W.C.T.U. matron at the railroad station had done similar work on a smaller scale, Portland did not officially establish a Traveler's Aid Association until the 1905 Lewis and Clark Exposition enlivened the city. The Lewis and Clark Exposition was a grand months long event in the tradition of the World's Fair. It was organized with the hopes of attracting new residents, businesses and investment to Portland. ${ }^{70}$ This was civic boosterism at its best and it involved the construction of multiple buildings and exhibits with hopes of attracting over one million visitors for the five month long Exposition. The Expo also created thousands of temporary jobs for young women. ${ }^{71}$ Advertisements of high wages not only lured women to 
employment within the fair but also in the downtown saloons, which hoped to be filled with Exposition visitors.

Previous expositions in Buffalo and Chicago had organized Traveler's Aid Associations to protect against the threat of white slavery, or the kidnapping and forced prostitution of women. While the white slavery hysteria had not yet peaked, there was a growing concern about the perceived dangers for young single females traveling alone. A temporary Travelers' Aid Association was established in Portland prior to the start of the Lewis and Clark Exposition. Lola Greene Baldwin, a fairly new resident to Portland who had distinguished herself in the national anti-vice and temperance movements, was appointed head of Portland's Travelers' Aid. ${ }^{72}$ Local anti vice activist, Rabbi Wise commented that the Lewis and Clark Exposition could both promote the "material interests" of men and the "moral and spiritual interest" of women through this new organization that had mobilized to protect the thousands of girls who "troop unprotected into the city.,"73

Lola G. Baldwin and the Travelers' Aid Association investigated job advertisements to determine if employers' claims were true and if the job offered respectable employment for young, women. Prior to the opening of the fair, Baldwin launched an investigation into the women who worked at local massage parlors. Of the dozens of massage shops in Portland, she claimed only nine were respectable and licensed and in the remainder worked "as many as four or five women of disreputable character. ${ }^{74}$ In addition to investigating employment opportunities, the organization, 
whose offices were housed in the Y.W.C.A., developed a room registry of lodgings they considered decent.

Once the Exposition began, Travelers' Aid workers wearing orange ribbons, met women arriving at the train station and docks. The workers offered women job referrals and free medical care through Good Samaritan Hospital. By the close of the Lewis and Clark Exposition, the Travelers' Aid Association had assisted 1500 young women, providing one third of them with "safe" employment positions. ${ }^{75}$

The Exposition attracted 2.5 million visitors to Portland, but not all of them left at the close of the fair. ${ }^{76}$ Baldwin commented that after the fair closed she was "busier than ever." and one woman, arrived at a position referred to her by the Travelers' Aid Association and found fifteen women already waiting to apply. By January 1906 a lack of funds and internal squabbling briefly disbanded the Travelers' Aid Association. The Y.W.C.A. eventually agreed to assume the organization in the name of "protection for girlhood. ${ }^{, 78}$ By the end of 1906 the association had assisted two thousand young women. ${ }^{79}$ After helping over 2,000 more women the next year, City Council Ways and Means Committee recommended $\$ 3000$ in public funding to the Traveler's Aid Association and a three person paid staff to continue their work.

During her work with Traveler's Aid, Lola G. Baldwin became convinced that local women, not transients, were associated with vice conditions in the city. After her 1908 appointment to the police force and the subsequent founding of the Women's Protective Division, Baldwin shifted her focus from assisting transient single women 
to combating prostitution in Portland. The Women's Protective Division however, continued to promote some of the work of the earlier Traveler's Aid Association. In 1911, Baldwin's Department for the Public Safety of Women provided 147 lodgings and 570 meals to women and girls ${ }^{80}$ By 1920 , the Women's Protective Division had a full time dance inspector, who patrolled the bright lights neighborhoods charity girls and other working women frequented.

In addition to job and housing referrals, middle class women's clubs financed and managed homes for working women. One the first of these homes was established by the Portland Women's Union in the 1890s. In 1905, the Volunteers of America opened a home at 385 Ankeny Street on the east side between Union and Grand. ${ }^{81}$ It contained twelve rooms and could accommodate twenty young women, with plans to expand to house fifty. One room was reserved for "worthy girls" stranded during the Lewis and Clark Exposition. A room with board and a telephone cost $\$ 2.50$ a week. In 1914, the Sisters of Mercy established a similar "nonsectarian" boarding home at 316 N. $16^{\text {th }}$ Street that offered free laundry and a library in addition to room and board ${ }^{82}$ By 1913 , The Catholic Women's League Association, and the Nurses Registry also housed women or offered room referrals. ${ }^{83}$ Working women's homes had parlors, laundry services and provided access to reading material, a piano and a sewing machine.

The primary purpose of the Volunteers of America's home and others like it was not to provide cheap room and board for working women. There were far more affordable options in rooming houses, with private families or in commercial lodging 
houses. What the founders and supervisors of working women's homes really sought to provide was a protected environment that would replicate the patriarchal family. The decline of supervised boarding houses and emergence of commercial rooming houses alarmed some middle class women. In 1908, Blanche Rafalsken wrote in the Oregon Journal, that furnished rooms provided no meals for "bachelor girls" and decried the loss of supervision boarding house landladies had once provided. ${ }^{84}$ The Big Sisterhood, an organization associated with the Y.W.C.A., called in 1918 for a mid-priced boarding home for working women. They stated, "We find, trying to help these girls help themselves, that the problems we have to deal with are largely caused by lack of proper living conditions and lack of proper supervision. At present all the homes with proper supervision are full to overflowing and have long waiting lists, with the result that the girls are living unsupervised in cheap hotels and rooming houses." 85

There was clearly a high demand for the rooms in working women's homes. The prices were affordable and the accommodations were comfortable. These homes were known for their good board and luxuries such as sewing machines, laundry services and libraries they provided. The matrons and benefactors of such homes, however, took their supervisory missions very seriously. In Portland working women's homes, an applicant needed to provide references to prove her "good character." 86 The homes had early curfews and some had mandatory religious services. Those that allowed women to visit with men restricted the hours they could call and forced them to remain supervised in the parlor. A working woman in New York in 
1915 commented about that she would not live in a supervised home "if you paid me for it. There are too many restrictions. I don't know hardly anyone in the city and all I do evenings is to sit in my room by myself. But I'm free and those girls aren't.", ${ }^{87}$ Mamie Pinzer, a reformed prostitute commented "the atmosphere at such a place would make me want to do something hideously wicked just to see what it was like." By the 1920 s, as women gained access to apartment rentals, the number of boarders in charitable homes declined. ${ }^{89}$ The working women's homes became temporary lodgings where new arrivals to the city could meet other women to room with outside of the supervised home.

In addition to social and protective services, many women's clubs sought legislative action to remedy the plight of working women. Unlike the middle class dominated campaigns for Traveler's Aid and the construction of boarding homes, the effort to improve working conditions for women and children was endorsed and promoted by a fragile alliance of working and middle class women. The Portland Women's Club was one of the first middle class women's organizations to become overtly involved in local political struggles. Around the turn of the century, the Portland Women's Club cooperated closely with the working class Portland Working Women's Club. The two organizations collaboration resulted in the passage of an ordinance, in 1900 , to close retail shops at 6 p.m..$^{90}$

On November 11, 1902 the Portland Women's Club petitioned City Council to create a Portland chapter of the Consumer's League. ${ }^{91}$ The Consumer's League was an organization that emerged from the Working Women's Society in New York City, 
which would later become the Women's Trade Union League a national alliance of working and middle class women who mobilized around labor issues. After its incorporation in 1898, the Consumer's League president, Florence Kelly began a speaking tour of the United States, one of her stops was Portland. Kelly urged middle class women to use their powers as consumers on the behalf of female employees in the places they shopped.

Members of the newly formed Portland Consumers League took the pledge, "I will not make purchases after five o'clock on any day, not after twelve o'clock on Saturdays and that if a package cannot be delivered before six o'clock on any day it is to be delivered the following morning."

In 1903, a coalition of middle and working class women from all over the state lobbied the legislature to pass a law that limited women's workday to ten-hours and the work week to sixty-hours. Oregon was "at the forefront of a national movement to regulate working hours and conditions." ${ }^{.92}$ In 1905, however, Muller, a commercial laundry operator, challenged the law in the courts claiming that the state had no right to interfere in the labor contract. The case eventually went before the Supreme Court. In a lengthy brief, Louis Brandeis argued on the behalf of Oregon that long hours negatively affected women's reproductive capacity and would have repercussions on future generations. The judges agreed and in 1908 the court upheld the ten-hour day law in Muller vs. Oregon.

In the majority opinion, Justice David Brenner wrote that "long hours on the feet tends to injurious effects upon the body, and as healthy mothers are essential to 
vigorous offspring, the physical well-being of women becomes an object of public interest and care in order to preserve the strength and vigor of the race." ${ }^{, 93}$ Female workers had won the right to shorter hours because of their biological capacities as women and not because of their status as laborers. Both the middle class women who fought for the rights of female workers and working class men shared the beliefs that women's proper place was the domestic sphere. Middle class women chose to reform women's working conditions, to preserve their status as future wives and mothers but working class men viewed their female counterparts as a threat to their wages and fought instead for men to be paid a family wage, so women would not have to be in the work force. Although women pioneered the sit down strike and won important labor battles, they were not well represented in the trade union movement. Working class women instead organized with their middle class counterparts to gain rights as laborers. These gains eventually proved significant for all workers and the Muller $v$. Oregon decision was used to justify a ten-hour day for all.

Although the ten-hour day law was upheld, many employers continued to violate it. In 1913, the Consumer's League utilized new social science methods to conduct a survey of working women in Portland to determine how well child labor and ten-hour day laws were being enforced. ${ }^{94}$ Their results found rampant violations and the conditions white single working women lived under shocked the public. In 1919, Oregon passed a series of laws that limited women to working a nine-hour day and a forty eight hour, six day week. ${ }^{95}$ Women were banned from working at night and could not work two consecutive days without a nine hour rest period in between. For 
every six hours worked, a forty-five minute break was mandated. This law exempted cannery and fruit packing workers. These women had no limits on the hours they could work, but they had to be paid overtime after ten hours of work.

Domestic workers were also exempted from laws regulating women's work hours. The Oregon commission that was set up in the mid 1920s to study labor conditions and create a minimum wage for women did not examine the conditions of domestic workers. This was partly a result of the class bias of women who advocated for such legislation. Although a multi class alliance promoted wage and hour regulations, it was middle class women who were in leadership positions. Claire Helene Barker, a suffragist commented about her primarily middle class comrades, "she overlooks the disquieting fact that in the realm of her own household, where her authority is absolute, she has failed to convince the world of her power to govern." $" 96$ Middle class women reformers could not have participated in the Progressive and suffragist movements had it not been for the working class women who took care of their domestic responsibilities.

Domestic workers were also omitted from protective legislation because of racism. As other fields of work opened up to women, domestic labor became increasingly associated with blacks and immigrants. The entire middle class movement that emerged to protect working women from its outset was only concerned with the plight of young, white women. ${ }^{97}$ The Oregon Federation of Women's Clubs voted in 1902 to oppose the inclusion of black women's clubs in their membership. ${ }^{98}$ Black women's clubs not only fulfilled the same civic and cultural functions that white 
women's did, but they also created a sense of community within the small dispersed black population in Portland. In 1927, black women began their own branch of the YWCA.

Even the gains made for white working women were not enough to hold together the fragile alliance between working class and middle class women's organizations. ${ }^{99}$ Working class women began to resent the rules and regulations middle class women imposed in their social services. Middle class women complained that working women were "self centered" and saw the youth subcultures they created as threatening to traditional gender roles. By the time the Seattle general strike broke out in 1919 the coalition between middle and working class women had completely dissolved.

\section{Conclusions}

Even though women adrift challenged patriarchal structures by working and living outside of their traditional family roles, they continued to accept many of the gender constructs of the time. Most women lived adrift for a short period of time before getting married. Women did not join unions in large numbers and although working class clubs participated in campaigns to regulate hours and wages, most of the female political activism of the time was dominated by middle class organizations.

However, the working class female and male culture that emerged in the rooming house districts in Portland's North End and elsewhere sent a clear message that woman would no longer be domestic or sexual servants. White women who gained access to manufacturing, trades, retail and clerical occupations flocked to these 
jobs, despite their low pay and poor working conditions. These women rejected the class divisions that were so blatantly pronounced within household employment. Women adrift also challenged the institution of marriage by engaging in alternative sexual liaisons. Charity girls recognized the economic basis of sexual relationships between women and men and exploited them to their advantage. Joanne Meyerowitz traces the roots of the sexual revolution of the 1920 s to the working class subcultures pioneered by women adrift. Historians' failure to recognize the contributions of working class women made to changing sexual mores also omits the challenges their subcultures posed to class as well as gender relationships.

The middle class reform movements that created boarding homes and met young women as they entered the city were an attempt to not only reinforce gender roles but also to undermine the working class women's subculture that had emerged. Middle class reformers used employment bureaus to direct women into domestic service, which they relied on for their own liberation from traditional roles. Even the more multi class reforms for wage and hours ended up strengthening women's economic segregation, undermining demands for equal pay for equal work and supporting racial and ethnic divisions.

\footnotetext{
'U.S. Department of the Census, $12^{\text {th }}$ Census of the United States, 1900, Occupations Table 43.
} 
${ }^{2}$ U.S. Department of the Census, $14^{\text {th }}$ Census of the United States, 1920 Volume 3 Table 20.

${ }^{3}$ Joanne Meyerowitz, Women Adrift: Independent Wage Earners in Chicago 18801930 (Chicago: University of Chicago Press, 1988), vii.

${ }^{4}$ Lynn Weiner, From Working Girl to Working Mother: The Female Labor Force in the United States 1820-1980 (Chapel Hill: University of North Carolina Press, 1985), 36.

${ }^{5}$ Consumers League of Oregon, Report of the Social Survey Committee of the Consumers League of Oregon on the Wages, Hours and Conditions of Work and Standard of Living of Women Wage Earners in Oregon with Special Reference to Portland (Portland: National Consumers League, 1913), p. 21.

${ }^{6}$ Donald E Sutherland, Americans and Their Servants: Domestic Service in the U.S. from 1800-1920 (Baton Rogue: Louisiana State University Press, 1981), p.3.

${ }^{7}$ Consumers League of Oregon, Report, 29.

${ }^{8}$ Ibid, 22.

${ }^{9}$ Ibid, 19.

${ }^{10}$ City of Portland, Stanley Parr Archives and Records Center, Mayor's Messages and Municipal Reports, 1911, p.99.

${ }^{11}$ City of Portland, Stanley Parr Archives and Records Center, Vice Commission of Portland Fourth Report Complete Findings, 2001-059, 13/11, 1913 p. 195.

${ }^{12}$ Consumers League of Oregon, Report, 5.

13 "Washington States Determines Women's Cost of Living," Oregonian, 11 January 1914 , p.7.

${ }^{14}$ Consumers League of Oregon, Report, 22.

${ }^{15}$ U.S. Department of Labor Women's Bureau Radio Talks on Women in Industry, Bulletin \#36 (Washington: G.P.O., 1924), 8

${ }^{16}$ U.S. Department of the Census, $12^{\text {th }}$ Census of the United States, 1900 , Occupations, Table 43.

${ }^{17}$ Consumers League of Oregon, Report, 31.

${ }^{18}$ Ibid, 34.

${ }^{19}$ Vice Commission of Portland Fourth Report Complete Finding, 172.

${ }^{20}$ Consumers League of Oregon, Report, 34.

${ }^{21}$ Ibid, 35 .

${ }^{22}$ U.S. Department of the Census, $12^{\text {th }}$ Census of the United States, 1900, Occupations Table 24.

${ }^{23}$ Vice Commission of Portland Fourth Report Complete Findings, 157.

${ }^{24}$ Sutherland, Americans and Their Servants, .3 .

${ }^{25}$ Ibid, .5.

${ }^{26}$ U.S. Department of the Census, $12^{\text {th }}$ Census of the United States, 1900 , Occupations, Table 43.

${ }^{27}$ Sutherland, Americans and Their Servants, 98.

${ }^{28}$ Ibid, 120. 
29 "Fine Work Done At Industrial School," Oregon Journal, 4 May 1904, p. 13.

${ }^{30}$ City of Portland, Stanley Parr Archives and Records Center, Mayors Messages and Municipal Reports, 1915,135.

${ }^{31}$ City of Portland, Stanley Parr Archives and Records Center, Mayors Messages and Municipal Reports, 1923, p. 498.

${ }^{32}$ U.S. Department of Labor Women's Bureau, Domestic Workers and Their Employment Relations: A Study Based on the Records of the Domestic Efficiency Association of Baltimore, Maryland, report prepared by Mary Robinson, Bulletin \#39, (Washington: GPO, 1924), 16.

${ }^{33}$ Consumers League of Oregon, Report, 42.

34 Thirteenth Census, Occupations, Table VII

${ }^{35}$ Consumers League of Oregon, Report, p. 25.

${ }^{36}$ Betty Israel, Bachelor Girl: The Secret History of the Single Woman in the

Twentieth Century (New York: Harper Collins 2002), 86.

${ }^{37}$ Consumers League of Oregon, Report, 28.

${ }^{38}$ Israel, Bachelor Girl, 87.

${ }^{39}$ Vice Commission of Portland Fourth Report Complete Finding s, 188.

${ }^{40}$ Israel, Bachelor Girl, 88.

${ }^{41}$ Vice Commission of Portland Fourth Report Complete Findings, 186.

${ }^{42}$ Consumers League of Oregon, Report, 29

${ }^{43}$ U.S. Department of the Census, $12^{\text {th }}$ Census of the United States, 1900 , Occupations, Table $24,13^{\text {th }}$ Census Table VII, $14^{\text {th }}$ Census of the United States 1920

Volume 3, Table 20

${ }^{44}$ Consumers League of Oregon, Report, 37.

45 Ibid, 40.

${ }^{46}$ Israel, Bachelor Girl, 113.

${ }^{47}$ Consumers League of Oregon, Report, 41.

${ }^{48}$ Vice Commission of Portland Fourth Report Complete Findings, 183.

${ }^{49}$ Paul Groth, Living Downtown: The History of Residential Hotels in the United States (Berkeley: University of California Press, 1994), 90.

${ }^{50}$ City of Portland, Stanley Parr Archives and Records Center, Cheney Reports, 5000$02,7 / 16,1919,10$.

${ }^{51}$ Groth, Living Downtown, 94.

${ }^{52}$ Cheney Reports, 9.

${ }^{53}$ Ibid, 97

54 "An Army of Waifs," Oregon Journal, 27 August 1902, p.6.

${ }^{55}$ Cheney Reports, 2.

${ }^{56}$ Consumers League of Oregon, Report, 57.

${ }^{57}$ Meyerowitz, Women Adrift, 93.

${ }^{58}$ Israel, Bachelor Girl, 105.

${ }^{59}$ Consumers League of Oregon, Report, 60.

${ }^{60}$ Meyerowitz, Women Adrift, 76. 
${ }^{61}$ Groth, Living Downtown, 117.

62 An Army of Waifs, Oregon Journal 8/27/02, 6.

${ }^{63}$ Vice Commission of Portland Fourth Report Complete Findings, 180.

${ }^{64}$ Meyerowitz, Women Adrift, 111.

${ }^{65}$ City of Portland, Stanley Parr Archives and Records Center, Mayor's Official

Correspondence, A2000-03, 7/46, 1914

${ }^{66}$ City of Portland, Stanley Parr Archives and Records Center, Mayor's Messages and

Municipal Reports, 1905, p. 223.

${ }^{67}$ Vice Commission of Portland Fourth Report Complete Findings, 175-176.

${ }^{68}$ Meyerowitz, Women Adrift, 116.

${ }^{69}$ Sandra Haarsager, Organized Womanhood: Cultural Politics in the Pacific

Northwest, 1840-1920 (Norman: University of Oklahoma Press 1997), 6-10, 83.

${ }^{70}$ Carl Abbott, The Great Extravaganza (Portland: Oregon Historical Society, 1981).

${ }^{71}$ Gloria Elizabeth Myers, "Lola G. Baldwin and the Professionalization of Women's

Police Work. 1905-1922" (Master's thesis: Portland State University, 1993), 1.

72 "Its Work Needed: Rabbi Wise on the Travelers' Aid Association," Oregonian 16

April, 1905, p.10.

${ }^{73}$ Ibid.

74 “Will Close Up Massage Shops, Travelers' Aid Association Finds Them

Notorious," Oregonian, 21 May 1905, p.8.

${ }^{75}$ Myers, "Lola G. Baldwin", 7.

${ }^{76}$ City of Portland, Stanley Parr Archives and Records Center, Mayors Messages and Municipal Reports, 1905, 21.

77 "Girls Are In Need," Oregonian, 25 October 1905.

${ }^{78}$ Myers, "Lola G. Baldwin”, 9.

79 "Council To Aid Girls in Work," Oregon Journal 24 December, 1907, p.5

${ }^{80}$ City of Portland, Stanley Parr Archives and Records Center Mayor's Messages and Annual Reports, 1911, p. 538.

81 "Home For Working Girls," Oregonian 10 June 1905, p. 9.

82 "Nonsectarian Abode for Working Girls Conducted by Sisters of Mercy,"

Oregonian, 27 September 1914, p.16.

${ }^{83}$ Vice Commission of Portland Fourth Report Complete Findings, 185.

84 "When A Home is Not A Home," Oregon Journal 5 April 1908, p. 6

85 "Boarding Home is Chief Need for Girls," Oregon Journal, 20 December 1918, p.8.

${ }^{86}$ Vice Commission of Portland Fourth Report Complete Findings, 185.

${ }^{87}$ Meyerowitz, Women Adrift, 86.

${ }^{88}$ Weiner, From Working Girl to Working Mother, 58.

${ }^{89}$ Meyerowitz, Women Adrift, 89.

${ }^{90}$ Haarsager, Organized Womanhood, 192.

${ }^{91}$ Ibid, 193, 247.

92 Ibid, 228, 248

${ }^{93}$ Weiner, From Working Girl to Working Mother, 45, 67

${ }^{94}$ Haarsager, Organized Womanhood, 239 
${ }^{95}$ U.S. Department of Labor Women's Bureau, State Laws Affecting Working Women: Hours, Minimum Wage and Home Work, Bulletin \#40 (Washington: G.P.O., 1924), p. $5,18,32$.

${ }^{96}$ Robinson, Domestic Workers, 2

${ }^{97}$ Weiner, From Working Girl to Working Mother, 32

${ }^{98}$ Elizabeth MacLagan, A Peculiar Paradise: A History of Blacks In Oregon 1788 1940 (Portland: The Georgian Press, 1980), 120.

${ }^{99}$ Haarsager, Organized Womanhood, 230 


\section{CHAPTER IV \\ SPORTING GIRLS: THE PROSTITUTION ALTERNATIVE}

Women adrift were viewed by reformers as the "worthy" homeless who needed to be protected from the depravity of their "unworthy" prostituting sisters. In the early twentieth century prostitutes were connected to the homeless man and both these populations were seen as threats to social stability and traditional morality. Prostitutes often lived and worked in the same neighborhoods homeless men resided in, and were often prosecuted under the same statues that were used to control and criminalize male transients. For many women, prostitution was a sensible alternative to living and begging on the streets. Other women just could not tolerate the low wages, poor working conditions and lack of material comforts suffered by women adrift. Instead, these women sacrificed their reputations and the respectability and become prostitutes. In 1910, prostitutes could earn two to three times the average wage of a male sales clerk. $\quad$ Both prostitutes and non-prostitutes viewed "sporting" or the sex trade, as easier than factory work or domestic labor, ${ }^{2}$ One S.W. Portland woman who sported said, "What is there to living a respectable life after all? You don't get any credit for it and there's nothing in it." ${ }^{3}$ She had left her adulterous husband and fell into prostitution when she arrived penniless with her children in Portland. She took the $\$ 600$ to $\$ 700$ she earned each month sporting and running a brothel, and sent her children to good boarding schools.

In the early twentieth century, women had ample opportunity to work in the sex trade. Prostitution had become commercialized in the $18^{\text {th }}$ century as the nation began to urbanize, and by the dawn of the twentieth century, it was open and tolerated 
in every city ${ }^{4}$ Prostitution was so widespread that in 1900, Muncie Indiana, a town of 11,000 had over 20 brothels with four to eight women residing in each. ${ }^{5}$ In 1911 , it was estimated that 3000 women worked as full-time prostitutes in Portland. ${ }^{6}$ In some places, prostitution was restricted to a centralized red light district, often near the skid row areas homeless men frequented. In Portland, no officially sanctioned red light district existed, but vice was concentrated in the Whitechapel district, a one square mile neighborhood with in the North End of downtown, which was also home to many transient men.

The density of prostitutes in the city of Portland was not surprising considering the gender composition of the city's population. In 1900, there were 1.4 males for every female in the city. ${ }^{7}$ A significant portion of the male workforce was single transient laborers who worked in the farms and forests that surrounded the city. Many came to Portland in the winter ready to spend their meager wages. In 1904 alone, 30,893 temporary lodgings were provided for men by charitable organizations. ${ }^{8}$ So "in the minds of some Portlanders prostitution was a required device to stave off all social chaos and prevent harm from befalling the nice young ladies of the community, it was a social safety valve for thousands of unemployed men who came to Portland each winter from the logging camps and lumber mills adjacent to the city." 9 These were the men who lived in and around the Whitechapel district.

Because of their geographic proximity and marginalization in the wider community, prostitutes were often considered to be the female incarnation of the transient, homeless man. Elected officials often lumped the two very publicly visible 
marginalized populations together. In 1903, Mayor George H. Williams conducted a campaign against prostitution "cribs" in the North End, which coincided with a crackdown on transient men. He proudly claimed that as a result of the anti-vice campaign, "few if any dissolute women now walk the streets soliciting men," and the establishment of a rockpile for homeless men, "has kept away many of this vicious and criminal class. ${ }^{\prime 10}$ Both the presence of women soliciting and unemployed men on the streets posed a threat to the social structure of the city, and the authorities felt the need to chase them out of public view.

Prostitutes and hoboes were not just easy scapegoats in political campaigns, they were also prosecuted under the same laws, namely the vagrancy statue. First adopted in 1887, a vagrancy charge in Portland could be leveled against "idle or dissolute persons including those without a visible means of support or employment, those who beg in public places or from house to house or who procure children to do so and those who live in or near houses of ill-fame." 11 In the late $19^{\text {th }}$ and early $20^{\text {th }}$ centuries vagrancy was a catchall charge that included loitering, soliciting, begging, and being on the streets with out any money.

Solicitation of potential customers on the street was part of the prostitution experience for some women, but there were class divisions within the sex trade. For a few women the monetary profits from prostitution were extremely high. Blanche, who left the North End for an apartment on the Park Blocks because she was "getting too notorious", made $\$ 75$ to $\$ 85$ a week from sporting and sometimes her earnings topped $\$ 100$. Blanche had an account in the Bank of California and owned land in 
Irvington. One upscale brothel, where the madam was the former wife of a wealthy Portlander, had a fourteen room house and three young women working there. She was known to "treat girls with great consideration" and the youngest, Katherine, was even given music lessons. ${ }^{12}$

For every upscale brothel and high paid prostitute there were dozens more who worked for much lower wages in poorer conditions. In one hotel on Colombia Street, the women who sported there were known as $\$ 2$ girls. ${ }^{13}$ They tried to supplement their earnings by selling beer and whiskey in their rooms at inflated prices and catered to a "large transient trade." Rosie, an Italian prostitute who lived and worked in a North Third Street lodging house with "uncleanly rooms" was a \$1 girl who took "anyone she could get" for a client. The rooming house's only modern convenience was an electric light, the furniture was broken and the carpet was "filthy rags". A proprietor of a nearby lodging house seemed to think that the one to two dollar girls have "no limit to their business, they never wear out." But one cheap prostitute gave a more telling account of her experience remarking, "I'm just about all in. This life will use me up and it don't take a very long time to do it either."

While wealthier brothels relied on high class social networks to spread the news of their services, one to two dollar girls had to solicit their own clientele. Some houses hired young men to hawk the women to males passing by. In one rooming house on Morrison Street, Jim and Dick, the elevator operators "secured patrons" for the traveling prostitutes who used the rooms to temporarily conduct business. ${ }^{14}$ In 
another bawdy house on the waterfront the girls "rustled on the street and bring in men."

Regardless of the class of the brothel, women in the sex trade shared the same difficult working conditions. In one brothel where the landlady and her husband lived with "forty canaries and assorted dogs" the women were "worked hard." Prostitutes in this house regularly saw 25 to 30 men each night. ${ }^{15}$ In Katherine's upscale brothel, she too saw twenty five to thirty men a night after her evening music lessons. Women who prostituted may have viewed their work as easier than twelve hours in a factory but it came at an emotional cost. Sporting women were stigmatized and shunned by respectable society and although prostitutes formed their own close-knit communities, many women suffered from society's scorn. Drug and alcohol use were common. ${ }^{16}$ In one hotel in downtown Portland women were "passed out drunk" and in the rooming house with all the pets one sporting woman was an "absinthe fiend." 17 Even the madam who ran the upscale brothel regularly "had to be carried to her room" because she had drunk too much. ${ }^{18}$

In addition to the emotional price they paid, sporting women suffered physical hardships, such as venereal disease and pregnancy. Women, who bore their children and continued to work, sent them to "baby farms" where a retired prostitute was paid to care for them. Venereal disease rates ran high in the early twentieth century and untreated gonorrhea and syphilis could cause sterility and early death. In the first report of Portland's Vice Commission issued in 1912, the committee discovered that venereal disease accounted for $21 \%$ of all disease in Portland. ${ }^{19}$ The physical and 
emotional prices of prostitution drove many women to take their own lives and as a result prostitutes had a much higher suicide rate than the general female population. ${ }^{20}$ A few prostitutes, like Maud, earned an estimated \$250 a month, but sporting women paid a high price to ply their trade. ${ }^{21}$ Women who sported were commonly charged 'bed money' by their madam, landlady or rooming house proprietor. Bed money cost many sporting women at least half of their earnings. Those women who worked independently could rent their own rooms, but they were regularly charged higher rents than their respectable counterparts. One hotel on West Park Street charged sporting women $\$ 15-\$ 18$ a day to rent a room. For hotel and rooming house proprietors it was more profitable to rent to prostitutes and many grew to prefer this clientele. One apartment house owner on Clay Street declared there was "hardly an apartment house in the city in which there were no sporting women. They are the best kind of people to get along with". Another observed that renting to prostitutes was "absolutely the only way either a rooming house or apartment house could be run in the City of Portland if one expects to make the business a success." 22

Despite the hazards of the work, many young women still viewed prostitution as the best of their limited options. Contrary to the fears and assumptions of middle class female reformers, most prostitutes were not recruited from the population of working women living in rooming houses. Most prostitutes entered the profession directly from their families' or husbands' homes. The only significant difference between sporting women and women adrift was the history of family instability in many prostitutes' backgrounds. Often women entered the trade because they were 
forced to support their relatives following the death or desertion of a husband or parent. The most common profession for women who had worked outside of the home prior to prostitution was domestic work. In 1912, out of the total numbers of women arrested for vagrancy in Portland, $17 \%$ had worked as domestics and $10 \%$ as housekeepers. ${ }^{23}$ Wives accounted for $14 \%$ of the occupations listed while dressmakers only made up $6 \%$.

\section{Portland: A Wide Open Town 1900-1908}

In 1901, Portland was considered a "wide open town", where prostitution and gambling were not only rampant but by default, legal. ${ }^{24}$ Although vice resorts could be found throughout Portland's downtown, much of the activity was concentrated in the Whitechapel district and near skid row in the North End. One man remembered his first trip to Portland in the early 1900 's:

When I first walked north on $4^{\text {th }}$ Avenue, I was startled to find it bordered with one and two story frame buildings like little shops each with a window against the sidewalk and a woman inside. Over the door was a girl's name Jennie, LuLu, May Yvonne, The Favorite or another. I quickly tumed around and walked back to Oak Street. Later when I had a bicycle, I rode down the street, not so close to those windows and found the rooms stretched for blocks on both sides of the street. At that time women and even young girls wore long skirts sweeping the sidewalk, or at least below their shoe tops. It was a jolt when a girl with a skirt above her knees would venture out of her crib and wave at me. The Red Light District spread on to other avenues besides $4^{\text {th }}$ as one came to Davis and Everett Streets. And though these cribs were all in this part of the city, I saw women stand at the side doors of saloons as far south as Salmon Street accost men as they passed and lead them up the stairwell. ${ }^{25}$ 
The overt nature of prostitution in U.S. cities sparked a national reform movement. Although prostitution had been a target of religious groups in the early to mid nineteenth century, it did not become defined as a widespread social problem until the late 1800 s. In the 1880 s and 1890 s the social purity movement sought to abolish prostitution and transform the sexual mores of the nation. Although the social purity ideology believed in a woman's right to refuse sexual relations and even acknowledged the existence of marital rape, it was by no means a feminist philosophy. Social purity reflected the Victorian sexual double standards of the time and advocated for sexual restraint among men and set up missions to rescue prostitutes from their lives of "female depravity." 26

The social purity movement pushed for moral reform but failed to understand the political economy of urban vice. In Portland, prostitution was a profitable business that created fortunes for many downtown real estate interests. Although gambling and prostitution were technically illegal, city and police officials worked hard to keep Portland a wide open town. Brothels and bawdy houses paid off the police to protect their establishment and some officers were regular customers of sporting women. In 1906, Officers Ellis and Richards got into an altercation with a Mrs. H., a hotel owner, after they brought two young prostitutes to a room they had rented. After Mrs. H. evicted the women, Ellis demanded his money for the room back from her husband and told him, "It's a good thing I did not lose my temper with your wife." ${ }^{27}$ Another officer paid to keep his consort in a brothel near the waterfront. 
While the police looked the other way, many of Portland's business class profited from prostitution activities. One Washington Street hotel owner commented that Portland was the most profitable vice city "even better than San Francisco.,"28 Property owners charged higher rents to operators of bawdy houses. It was estimated that owners received returns as high as $85 \%$ to $540 \%$ on properties rented for prostitution. ${ }^{29}$ City government, who tended to represent Portland's property owning class, fought to maintain Portland as a "lively town." Fred T. Merrill a councilman from the Third Ward from 1899-1905 ran on a platform to keep the city a wide-open town. Judge Henry McGinn, who never hid his love for vice, appealed to the Board of Police Commissioners to curb their crusade against prostitution at the turn of the century in order to protect business interests.

Although vice was profitable and quasi-legal in Portland, periodic crackdowns on prostitution and gambling were common. When George $\mathrm{H}$. Williams became mayor in 1902, he inherited a fast growing city population and dwindling monetary resources. Mayor Williams initiated a crackdown on the cribs that lined $4^{\text {th }}$ Avenue in order to raise revenue to beautify the city. ${ }^{30}$ Williams believed, "it is within our power and our plain duty to protect public decency and to that end it is my opinion that the cribs on the streets between the railroad depot and the hotels and elsewhere on our main streets should be suppressed and their inmates compelled to quit their business or move to more secluded quarters. Something at least would be gained for the appearance of the city if these people would occupy houses that have an air of respectability." 31 
Williams was not concerned with ending prostitution, he just wanted to create a cleaned up image for the city and make some fast revenue. ${ }^{32}$ Prostitutes were not the only targets of Mayor Williams's street sweeps, he also drove the hoboes and unemployed men from public view. Sporting women were driven from their ground floor cribs and expected to move elsewhere, but homeless men caught on the streets were sentenced to hard labor. Within one year, Williams proclaimed that, "few if any dissolute women now walk the streets soliciting persons to go to their abode... and fewer beggars are in public view...largely as a result of the rock pile." Williams managed to clean up the image Portland's streets, by driving the homeless and prostitutes off them, without ever cutting into the vice profits.

By the early 1900s, prostitution was quickly gaining attention as a pressing urban social issue. The social purity movement of the previous century had evolved into a philosophy of social hygiene. Although still steeped in the moral tenets and Victorian mores that defined social purity, the social hygiene movement utilized social science methodologies to not only attack prostitution on a moral basis but also to reveal the political and economic situation that perpetuated vice. Prostitutes were increasingly depicted as victims of both women's economic situation and more frequently of international syndicates, popularly known as the white slave trade who kidnapped women, forcing them into prostitution. In 1905, the Portland political machine was destroyed by a timber scandal which eventually led to the election of reform minded mayor and social hygiene activist Dr. Harry Lane. ${ }^{33}$ 
In $1905 \mathrm{Dr}$. Lane attempted to regulate prostitution in the saloons of Portland by introducing the Closed Box Ordinance. This ordinance forbade saloons from serving liquor in any room smaller than 160 square feet and also prohibited the side door entrances to saloons that many prostitutes used to lure customers to upstairs rooms. ${ }^{34}$ Although the police began enforcing the ordinance in the summer of 1905 , the city council, which continued to represent traditional business and real estate interests, voted to repeal the ordinance soon afterwards. The weak mayor system Lane operated under undercut many of his attempts at reform. During Lane's two mayoral terms, the city council overrode half of his vetoes. ${ }^{35}$

Still Dr. Lane persisted and although the City Council denied his request for a bill to license vice businesses, he succeeded in ordering the closure of the Paris House brothel, one of Portland's largest in $1906 .^{36}$ Over one hundred women rented cribs in the Paris House, which had opened in 1904 to serve the expected crowds of visitors to the Lewis and Clark Exposition. Even after the successful closure of the Paris House, the police collusion with vice interests continued. In 1907, the Lane appointed a new police chief who fired and replaced the entire detective force. ${ }^{37}$ The mayor ordered the police to enforce existing laws against brothels. The police began closing bawdy houses in an "unobtrusive manner" and the mayor refused to support an oft proposed regulated red light district. ${ }^{38}$

Lane claimed this "work was not undertaken as a moral measure but as a matter of respect for the law," and that he would clean up every "bawdy house regardless of the consequences. ${ }^{39}$ Lane recognized that his campaign could not 
eliminate prostitution and many of the sporting women who were driven from downtown relocated their business to other parts of the city. Even the exclusive Portland Heights and Irvington neighborhoods began complaining about the presence of sporting women. For some women, however, the vice crackdown held far graver consequences. The newly formed Women's Protective Division, spent its first month of operation deporting Japanese, Russian and Chinese prostitutes. ${ }^{40}$ The campaigns against vice ended when Lane left office. His predecessor Joseph Simon represented the traditional West Side business interests and declared "vice can never be extirpated, but at Portland it is held now under closest possible restraint." ${ }^{41}$

\section{The War Against Vice In Portland: 1911-1918}

By 1910 , the national hysteria about the white slave trade had peaked. Muckraking journalists published stories about women and girls being kidnapped in public places and brought against their will to brothels. City streets were seen as dangerous places for white women. Although a national 1907 investigation into the white slave trade found evidence of the existence of prostitution rings, they were far

less prevalent than reformers and the press had suggested. ${ }^{42}$ Ironically, Chinese women, who were most often forced into prostitution, were seldom mentioned in press accounts or reformer's pamphlets. In 1910, Congress passed the Mann Act, which prohibited the transportation of women across state lines for the purposes of prostitution.

From 1910 to 1917 , forty-three cities launched formal investigations into vice conditions. In 1911, Mayor A.G. Rushlight responded to public pressure and 
appointed a fifteen member vice commission, which included three ministers and four doctors, to investigate the conditions in Portland. ${ }^{43}$ The commission was a result of pressure from the national and local social hygiene movement that had united broad interests against prostitution. The women's groups that joined the movement believed prostitution degraded the status of all females, doctors were involved to stop the spread of venereal disease, religious interests opposed prostitution on a moral level, and urban reformers hoped to draw attention to the low wages that drove women into prostitution. The four Vice Commission reports that were released over a year's time reflected these diverse interests.

The first Vice Commission report was issued in April of 1912. It focused on the spread of venereal disease in Portland and reported that $21 \%$ of all diagnoses in the city were for venereal disease. The city government took no local action after the issuance of this report. City residents, however were outraged and launched a recall drive against District Attorney George Cameron because of his connection to vice and liquor interests. On the state level, Governor Oswald West was appalled by the findings of the Vice Commission and the local authorities' lackluster response and pledged to travel to Portland to clean up the city. Mayor Rushlight responded with "I have no knowledge of any conditions in Portland that require cleaning up," but vowed to assist the governor.

Two days after Rushlight's adamant denial that vice existed in Portland, the commission released their second report. This report revealed that out of 547 hotels, rooming houses and apartments investigated, 431 preferred "immoral tenants" or 
ignored illegal conduct. ${ }^{44}$ The report also exposed the deep involvement of Portland business and real estate interests in vice. This time the city could not ignore the Vice Commission report and the Portland police responded by raiding 13 rooming houses in the North End. Governor West appointed a special prosecutor, Walter H. Evans, and a team of agents to investigate business and vice collusion. Mayor Rushlight proposed a regulated red light district for the city. West responded, "The real prostitutes I am after in Portland are the prostitutes in office" and kept the pressure on. ${ }^{45}$ Two months after the second vice commission report appeared, City Council passed the tin plate ordinance, a law that required hotels, apartment and rooming houses to post the names and addresses of the property owner in a visible place. It also required the licensing of rooming houses. This law was the first of its kind in the nation.

In 1913, Governor West was still frustrated with the lack of legislative response to vice in Portland and he introduced a state wide abatement ordinance that could close buildings for a year and confiscate the property inside them if they were used for "immoral purposes." 46 Prosecutors did not have to prove that the owners had any knowledge about the illegal activities going on in their buildings. Owners could avoid state seizure of their property if they cleaned it up. In the first eighteen months after the abatement law passed, sixty eight owners were prosecuted. In 1914, the district attorney declared the abatement law a successful way to combat houses of prostitution. However, he admitted, "as soon as houses which they are occupying achieve a degree of notoriety, they move elsewhere." ${ }^{47}$ 
Local housing regulations did not pass until 1918, under Mayor H.R. Albee. Article XVI of the housing ordinance required all hotels, rooming and lodging houses to have a license, which needed to be renewed each year. ${ }^{48}$ License applicants were required to supply the name of the property owner, three local references who could attest to the applicant's "good moral character" and their employment and residential history for the past five years. It also regulated how guests were recorded in hotel registers and forbade the rental of rooms to two unmarried persons of the opposite sex. Although the Oregon Hotelman's Association members either supported the ordinance or "did not have the courage to water it down," the national organization remarked, "This shows how far we are drifting on the sea of drastic law whenever some fellow wants to gain a little notoriety he proposes some foul hotel law and all the cranks turn in behind him. One can run a drugstore or take in boarders and give no account of himself., 49

One of the main complaints of the local hotel association was the appointment of Captain Harms as leader of the squad that would enforce the ordinance. The Ansonia Hotel got a taste of the investigative style of Captain Harms after a resident was arrested twice for vagrancy but not convicted. ${ }^{50}$ Miss N., the hotel proprietor complained the police visited the property at "all hours of the night." They wandered through to see if "all was jake" following young working women to their rooms. Miss N. was losing tenants from the continual police harassment. Although intended to suppress illegal activity, the licensing law had some unforeseen consequences. After one raid on a hotel, the Oregonian lamented the arrest and punishment of law-abiding 
guests along with disorderly ones. "In every hotel in the civilized world there is apt to be something going on and not one can stop it," rather than police raids and license revocation, the editorial suggested cooperation between the police and hotel owners to evict problem residents. ${ }^{51}$

There was racial bias in the enforcement of abatement laws and the granting of licenses. In 1919, two black women applied for a license to run the Willard Hotel. ${ }^{52}$ The police claimed the women only came to town to find "a place to sport," When the police went to their hotel one evening and the women were not in, they recommended a denial of their license application. After three weeks of waiting and finally having their application denied, the women left Portland for San Francisco. A Japanese hotel proprietor had his license revoked because he did not speak English, although it was eventually restored after a review by the district attorney. ${ }^{53}$ In 1922, a black owned cabaret was raided and had its license revoked because interracial couples were dancing. ${ }^{54}$ When the NAACP protested the license revocation, the City Council responded with a debate on an ordinance to ban racial intermingling, which did not pass.

Not only were licensing laws and housing reforms used to legislate social behavior and persecute marginalized populations, but they were also the means by which the city government promoted a specific type of population growth. In 1900, $31 \%$ of Portland's residences were owner occupied, single family dwellings. ${ }^{55}$ By 1910 , the percentage of homeowners had increased to $46 \%$. That decade was one of enormous population growth, much of it concentrated on the more suburban east side, 
along street car lines. ${ }^{56}$ Although this real estate boom attracted large numbers of families to Portland, city officials began to express concern about becoming like San Francisco, a "floater city" of transient working men. ${ }^{57}$ By issuing ordinances such as hotel licensing, the city ensured that "the man with a family" would be looked out for.

\section{The War Against Sporting Women: From Victim to Criminal}

As the hotel ordinances and Tin Plate laws were debated, very little attention was given to the fate of the sporting women who lived and worked in the downtown hotels and rooming houses. Governor West insisted that he was "not here to get these poor unfortunate women," but the Third Report of the Vice Commission proclaimed that anti-prostitution laws disproportionately targeted women. ${ }^{58}$ Between the beginning of 1911 and the summer of 1912,1504 women were arrested on prostitution related charges in comparison to 372 men. Ordinance \#14049 which prohibited the "frequenting" of prostitutes by men was only charged against 48 men, only $25 \%$ of who were convicted. Over half of women arrested for prostitution crimes were convicted.

Prior to the crackdown on vice, prostitutes could avoid arrest by paying off the police. Those who were convicted had the option of leaving town, just as homeless men were given at the time. In 1905, Minnie W. was convicted of vagrancy and asked to be allowed to return to her hometown of Tacoma. "That's a good idea," responded the judge, "you had best return and watch Tacoma grow." Even if a woman did pay a fine or do jail time, she often went right back to the sporting life. In 1911, $11.3 \%$ of those arrested on prostitution charges had been picked up at least once 
before, and $4 \%$ had been arrested anywhere from three to nine times previously. ${ }^{60}$ The exception to the general slap on the wrist for prostitution crimes was when black or Chinese women were arrested. In 1905, Sallie W. and Sadie H., two black women who resided in the North End, were picked up for vagrancy and then additionally accused of robbing their customers. Sallie claimed the police were "making war on her." ${ }^{61}$ In 1914, two Chinese women were arrested for being inmates of bawdy houses and deportation orders were immediately issued against them. ${ }^{62}$

The tolerance displayed by the legal system to white women convicted of prostitution reflected a somewhat sympathetic public opinion towards sporting women. The white slavery hysteria had painted an image of prostitutes as victims, who were in need of rescue. As the social hygiene movement began to utilize surveys and social scientific data collection to influence public policy, more attention was given to women's economic conditions that made prostitution appear to be such an attractive alternative. The Fourth Report of the Vice Commission investigated the poor labor and living conditions that drove working women to prostitution in Portland. ${ }^{63}$

Not all factions of the social hygiene movement viewed prostitutes in relatively positive light. Rather than innocent victims of evil men or economic circumstances, the new public health movement saw these women as a threat because they were potential carriers of a lethal disease. In 1905, the Wasserman test to detect syphilis was developed. ${ }^{64}$ By 1908 , Lola G. Baldwin ordered the Women's Protective Division to test all the women and girls, the office came in contact with, for syphilis. 
The female detective squad began using gloves to handle women's clothes. In 1909, after two young girls Baldwin has confined to the Louise Home, a social service institution for unwed mothers, escaped and allegedly had sex, Baldwin proposed incarceration for women with venereal disease.

Baldwin's proposal for a detention home for women did not immediately come to fruition, but in 1913, the state run Hillcrest School for Girls opened. ${ }^{65}$ There, twelve year olds could be committed to the institution until they were eighteen and eighteen to twenty five year olds could be held a maximum of 3 years. During this era, female delinquency was not necessarily defined by criminal behavior, but rather by "uncontrolled" sexuality. This could be interpreted as the use of coarse language, immodest dress, interracial mingling or smoking cigarettes. The Hillcrest School was considered a modern facility for its time, putting social work and social Darwinist principles into practice. Instead of punitive incarceration, women and girls were confined to cottages where they participated in farm and domestic chores to ensure their rehabilitation. ${ }^{66}$ Every inmate was administered an intelligence test, and those considered 'feeble minded' were forcibly sterilized, an outrageous practice which continued far into the twentieth century.

In 1914 the City Council endorsed Baldwin's idea for a detention home for women with venereal disease. ${ }^{67}$ The council allocated $\$ 15,000$ for the project and needed $\$ 8000$ more to purchase and build a facility on vacant land near the county poor farm in Troutdale. However, the money the council had approved was revoked as revenue became short that year due to a depression. In 1917, Mayor George Baker 
announced that funding had been found and construction began on the Cedars, a detention facility designed to "rid the community from the diseased women of the underworld., 68

The construction of the Cedars coincided with the entrance of the United States into World War I. While the military war was waged in the trenches abroad, a social and political war was conducted at home. Immigrants, socialists, unionists and anarchists all suffered from war-time repression. Women too became the targets of a peculiar campaign designed to protect the health of U.S. soldiers. The War Department organized the Committee for the Protection of Women and Girls, which set up regional departments and detention homes. ${ }^{69}$ In towns with army bases, curfews were established and women caught out after 9:00 p.m. could be forcibly detained and examined for venereal disease. Over 18,000 women who tested positive were quarantined for the duration of the war. Lola G. Baldwin, of the Portland Police Women's Protective Division, led the Northwest Regional Committee for the Protection of Women and Girls in San Francisco. Her office was responsible for the arrest of over 35,000 women during the war. ${ }^{70}$

When the Cedars detention facility opened up at the end of 1917 , over 200 women were detained within the first two months. ${ }^{71}$ The initial group of women who were released from the home after treatment asked for help in finding work because the facility failed to offer any. In 1918 a woman was hired to provide the inmates with job training skills and placement into domestic professions. ${ }^{72}$ Although the 1918 armistice ended World War I, the Cedars remained in operation. Eventually, the 
Health Department recognized that detaining women with venereal disease was unfair considering men were tested, treated and released men but they claimed "though most girls are locked up against their will...no girls complain about their treatment or care." ${ }^{, 73}$ The state began reimbursing the home for the women detained there and in 1921, they paid two dollars a day for the care of 673 women. The average age of a woman incarcerated at the Cedars was seventeen. She usually stayed four months and during that time she sewed her own clothes and performed daily chores in the kitchen and garden.

By the 1920s prostitution had not only become a criminal act punishable by incarceration but it was also a psychological disorder. ${ }^{74}$ Before World War I sexuality had been couched in terms of male/female but after the war relationships were classed as normal/abnormal. While women's sexuality was finally becoming acknowledged, prostitution, lesbianism and promiscuity were viewed as the antithesis of normal female sexuality. Prostitutes were now not only being arrested under anti-vice ordinances but they were also in danger of being committed to institutions for the "feeble minded" and insane.

As public opinion of prostitutes shifted from "innocent victim to sinister polluter," control of the trade was taken out of the hands of women and placed under the direction of men. ${ }^{75}$ Prior to the nineteenth century, many prostitutes were selfemployed and women cycled in and out of the trade. As the century wore on and urbanization increased, prostitution was commercialized and women practiced as professionals in hierarchically organized houses controlled by a madam, and often 
located in a red light district. Pimps were not usually part of the operation. It is not until 1905 that the first mention of the "macquereaux" class is made in Portland. ${ }^{76}$ The reference is made in connection with the briefly enforced box ordinance. As the back rooms of saloons where women solicited were closed down, male bartenders and boyfriends helped sporting women find customers. By the 1920 s, vice crackdowns had closed the red light districts across the nation. As prostitution was driven underground and a new class of managers arose, the pimps, and the modern day associations of violence, abuse and addiction with the sex trade developed.

\section{Conclusions}

Among the categories of homeless women, prostitutes were viewed as the "unworthy" poor and their existence was used by reformers to justify improving labor and living conditions for young, white, single working women. Prostitutes however, did not benefit from these reforms and as labor conditions for women were improving, the sex trade was becoming criminalized. Early reformers set up homes to rescue prostitutes and return them to their rightful place as domestic employees in a middleclass homes. These rescue missions did offer a valuable service for women who could no longer tolerate the difficult physical, emotional and social toll prostitution took on them. But, rescue homes and later the anti-vice movement failed to take into account the women's motivations for entering the trade.

Economics definitely played a role in many women's decision to turn to prostitution but wages alone were not the only motivating factor. Some women sought out prostitution for its easy money but others preferred it to the drudgery and 
demoralization of domestic work and the entrapment of marriage. Not only did antivice campaigners ignore women's motivations for entering prostitution but their fate was overlooked too. Each anti-vice crusade made it more difficult for prostitutes to operate independently in Portland. Wealthy brothels probably remained protected by the police and business interests but one to two dollar girls were forced on to the streets or under the protection of the macquereaux class.

These campaigns also impacted homeless men. Housing reforms like hotel licensing were intended not just to crack down on vice but also to create a singlefamily paradise out of a wide-open floater city. Licensing laws made it more difficult to operate a cheap lodging house that rented to either gender. Homeless men and prostitutes were once again brought together, by geography and also their housing choice.

While the homeless man represented a threat to the labor market and political stability, prostitutes were viewed as a threat to the patriarchal family. The commercialization of sex took away a women's power in the home and her marriage. Reform minded women understood that prostitution threatened the status of all women. Rather than challenge gender roles or patriarchal family relationships, these middle class reformers chose to target prostitutes. They played upon the ideology of women's dependence in the early years of the twentieth century but as the success of women's political action in anti-vice campaigns eventually helped realize female suffrage, the prostitutes on whose plight female reformers had launched their movement became criminalized. 
${ }^{1}$ Lois W. Banner, Women in Modern America: A Brief History (New York: Harcourt Brace Jovanovich Inc., 1974), 81.

${ }^{2}$ Ruth Rosen, The Lost Sisterhood: Prostitution in America 1900-1918 (Baltimore:

Johns Hopkins University Press 1982), 167.

${ }^{3}$ The Vice Commission of Portland, Second Report of the Portland Vice Commission To the Mayor and City Council of the City of Portland Oregon, August 1912, 19.

${ }^{4}$ Rosen, The Lost Sisterhood, 2.

${ }^{5}$ Banner, Women in Modern America, 76.

${ }^{6}$ E. Kimbark MacColl, The Shaping of a City: Business and Politics In Portland Oregon 1885-1915 (Portland: The Georgian Press Company, 1976), 409.

${ }^{7}$ U.S. Census Department, $12^{\text {th }}$ Census of the United States, 1900, Population

${ }^{8}$ U.S. Census Department Census of Benevolent Institutions, 1904 Temporary Homes.

${ }^{9}$ Mac Coll, The Shaping of a City, 409.

${ }^{10}$ City of Portland, Stanley Parr Archives and Records Center, Mayors Messages and Municipal Reports 1903, 28.

${ }^{11}$ Amelia Ann Feary, The Origins and Development of Family Social Work in Portland Oregon (Master's thesis: University of Oregon, 1936), 133.

${ }^{12}$ The Vice Commission of Portland, Second Report, 18, 44.

${ }^{13}$ Ibid, 9,33-36.

${ }^{14} \mathrm{Ibid}, 8,28$.

${ }^{15}$ Ibid, $40,44$.

${ }^{16}$ Rosen, The Lost Sisterhood, 99.

${ }^{17}$ The Vice Commission of Portland Second Report, 25, 40.

${ }^{18}$ Tbid, 45.

${ }^{19}$ City of Portland, Stanley Parr Archives and Records Center, Auditor Historical

Documents, The Vice Commission of Portland, First Report, A2001-059, 15-07-19-1, 1912, 3 .

${ }^{20}$ Rosen, The Lost Sisterhood, 99.

${ }^{21}$ The Vice Commission of Portland, Second Report, 9,11,12, 17.

${ }^{22}$ Ibid, 65.

${ }^{23}$ The Vice Commission of Portland, Fourth Report, 96.

${ }^{24} \mathrm{Mac}$ Coll, The Shaping of a City, 228, 258.

${ }^{25} \mathrm{Mac}$ Coll, The Shaping of a City, 258.

${ }^{26}$ Rosen, The Lost Sisterhood, 11.

${ }^{27}$ City of Portland, Stanley Parr Archives and Records Center, Mayor's

Correspondence, Lane, A2000-003, 3/36.

${ }^{28}$ Ibid, 51 .

${ }^{29}$ Mac Coll, The Shaping of a City, 236,237, 404.

${ }^{30}$ Ibid, 253.

${ }^{31}$ City of Portland, Stanley Parr Archives and Records Center, Mayor's Messages and Municipal Reports, 1902, 1903, 20, 28.

${ }^{32}$ Mac Coll, The Shaping of a City, 234.

${ }^{33}$ Mac Coll, The Shaping of a City, 257. 
34 "Against the Closed Box," Oregonian, 20 July 1905, 14.

${ }^{35}$ Mac Coll, The Shaping of a City, 315, 327.

${ }^{36}$ City of Portland, Stanley Parr Archives and Records Center, Mayor's Messages and Municipal reports 1906, 223.

${ }^{37}$ Mac Coll, The Shaping of a City, 327.

${ }^{38}$ City of Portland, Stanley Parr Archives and Records Center, Mayor's Messages and Municipal Reports, 1908, 21.

${ }^{39}$ City of Portland, Stanley Parr Archives and Records Center, Mayor's

Correspondence Lane, A2000-003, 0256-01, 1908.

${ }^{40}$ Gloria Elizabeth Myers, "Lola G. Baldwin and the Professionalization of Women's

Police Work 1905-1922" (Master's thesis, Portland State University, 1993), 67.

${ }^{41}$ Mac Coll, The Shaping of a City, 382.

${ }^{42}$ Rosen, The Lost Sisterhood, 14, 19.

${ }^{43}$ Mac Coll, The Shaping of a City, 401-403.

${ }^{44}$ Portland Vice Commission, Second Report, 7.

${ }^{45}$ Mac Coll, The Shaping of a City, 404-409.

${ }^{46}$ Mac Coll, The Shaping of a City, 411.

${ }^{47}$ City of Portland, Stanley Parr Archives and Records Center, Mayor's Official Correspondence, A2000-003, 6/13, 1914.

${ }^{48}$ City of Portland, Stanley Parr Archives and Records Center, Ordinance \#34046 Article VXI p.28-30

${ }^{49}$ City of Portland, Stanley Parr Archives and Records Center, Miscellaneous Correspondence Hotels 1918, 0205-01, A2000-003, 10/11,1919.

${ }^{50}$ City of Portland, Stanley Parr Archives and Records Center, General Correspondence, Hotel Licenses, A2000-003, 16/78, 1919.

51 "Morals Raid Wrong," Oregonian, 14 March 1915, p.20.

${ }^{52}$ City of Portland, Stanley Parr Archives and Records Center, General Correspondence, Hotel Licenses, A2000-03, 16/32, 1919.

${ }^{53}$ City of Portland, Stanley Parr Archives and Records Center, General Correspondence, Hotel Licenses, A2000-003, 16/34, 1920.

${ }^{54}$ Elizabeth Mac Lagan, A Peculiar Paradise: A History of Blacks in Oregon $1780-$ 1940 (Portland: The Georgian Press, 1980) 137.

${ }^{55}$ U.S. Bureau of the Census, Thirteenth Census of the United States 1910, Table 13.

${ }^{56}$ Carl Abbott, Portland: Gateway to the Northwest (Tarzana, CA: American

Historical Pres, 1997), 94.

${ }^{57}$ City of Portland Stanley Parr Archives and Records Center, Auditor's Historical Documents, Cheney Reports, 5000-02, 7/6, 1918, 15.

${ }^{58}$ The Portland Vice Commission, The Third Report of the Portland Vice

Commission: The Legal and Police Aspects of the Social Evil 1912, 90-91.

${ }^{59}$ Oregonian 22 July $1905,6$.

${ }^{60}$ The Vice Commission of Portland, Third Report, 96

${ }_{61}$ "Closed Box Ordinance," Oregonian, 19 July 1905, p 11.

${ }^{62}$ Slave Girls Deported, Oregonian, 13 January 1914, p. 2. 
${ }^{63}$ The Portland Vice Commission, The Portland Vice Commission Fourth Report: A Report on the Economic Aspects of the Social Evil, 1913.

${ }^{64}$ Myers, "Lola G. Baldwin", 51.

${ }^{65} \mathrm{Ibid}, 40,59$.

${ }^{66}$ Rosen, The Lost Sisterhood, 21.

${ }^{67}$ City of Portland Stanley Parr Archives and Records Center Mayor's Messages and Municipal Reports 1914.

${ }^{68}$ City of Portland Stanley Parr Archives and Records Center Mayor's Messages and Municipal Reports, 1917, 5.

${ }^{69}$ Barbara Mel Hobson, Uneasy Virtue: The Politics of Prostitution and the American Reform Tradition (New York: Basic Books, 1989), 175-6.

${ }^{70}$ Myers, "Lola G. Baldwin", 89.

${ }^{71}$ City of Portland Stanley Parr Archives and Records Center, Mayor's Messages and Municipal Reports, Board of Health Report, 1917, 300.

${ }^{72}$ City of Portland Stanley Parr Archives and Records Center, Mayor's Messages and Municipal Reports, 1918, 306.

${ }^{73}$ City of Portland Stanley Parr Archives and Records Center, Mayor's Messages and Municipal Reports, 1921, 380.

${ }^{74}$ Hobson, Uneasy Virtue, 180-190.

${ }^{75}$ Rosen, The Lost Sisterhood, 47, 70.

${ }^{76}$ City of Portland Stanley Parr Archives and Records Center, Mayor's Messages and Municipal Reports, 1905, 21. 


\section{CHAPTER V \\ THE UNFORTUNATE POOR: BREADWINNING WOMEN AND THEIR CHILDREN}

The women who lived adrift during the early twentieth century were assumed to be single and only responsible for supporting themselves. Although their family's poverty was a determining factor in many of these women's decisions to leave home, not much attention has been paid to their relationships with the people they left behind. At least half of the women who lived adrift sent funds back to support family members. ${ }^{1}$ According to Rosen, many prostitutes also sent money home, although they may not have disclosed its source. ${ }^{2}$ The common perception of working women before the 1920's was that they were primarily single, never married, childless and not responsible for the support of dependents.

Working women were a diverse group with married, divorced, abandoned and unmarried mothers and widows among them. Many of these women were breadwinners, who not only supported themselves but also cared for dependents on their meager wages. In $1910,5 \%$ of the female population between the ages of 25 and 44 in Portland were widows and $2 \%$ were divorced. ${ }^{3}$ These child bearing aged women were likely to have dependents to support in addition to themselves. Older women could rely on their grown children for support, but many younger women did not have children old enough to work. In order to survive, women either had to find paid labor in addition to their domestic duties, find another male breadwinner or find an alternate means of support for their children. Many women were forced to rely on charities or temporarily give up their children in order to earn a living. 
Children who could not be cared for by relatives were temporarily sent to an institution, such as the Portland Ladies Relief Society's Children's Home. The founders of these institutions thought of children of single mothers as "homeless". ${ }^{4}$ In 1913, even children who remained in the home of their single working mother were considered "to a degree homeless."

From 1850 to 1910 , the numbers of out of wedlock births in the United States doubled. ${ }^{6}$ While illegitimacy had existed throughout history, Regina Kunzel suggests that the stigma attached to unmarried mothers and their children reached new heights in the late nineteenth and early twentieth century. ${ }^{7}$ During colonial times, out of wedlock birth was frowned upon, but communities offered economic support to single mothers and their children. By 1900, unwed motherhood had become so socially unacceptable that many unmarried pregnant women were kicked out of their homes or sent away to an institution until they gave birth. The maternity home movement sought to remedy the plight of unwed mothers by providing them with a caring home that could prepare them the responsibilities of motherhood. One such place, Portland's Salvation Army Rescue Home, euphemized out of wedlock pregnancy by referring to their charges as "homeless" women. ${ }^{8}$

\section{Survival Strategies for Breadwinning Women}

Prior to 1920 , the breadwinning woman was seldom considered in popular discussions about working women. The Consumer's League of Portland defined, 
"the widowed or deserted woman with dependent children as another example of a woman adrift," but did not make much reference to the unique living or working conditions of single mothers. ${ }^{9}$ Single mothers had few options other than work to support their family. In the 1890 s in Portland, $47 \%$ of divorced women worked and $28 \%$ of widowed women worked, compared to $19 \%$ of single women. ${ }^{10}$ By 1900 , widowed women made up $12 \%$ of the female workforce in Portland and divorced women comprised $4 \%{ }^{11}$

Although widowed and divorced women were engaged in many of the same occupations as their single counterparts, they were more heavily concentrated in the domestic trades. In $1900,57 \%$ of widowed working women and $47 \%$ of divorced women worked as domestics while only $40 \%$ of the single women did. Widowed and divorced women were underrepresented in sales positions, only $8 \%$ of working widows and $12 \%$ of divorcees were sales clerks compared to $26 \%$ of single working women. ${ }^{12}$

Wage earning women had to find creative ways to continuing caring for their young children while working. Some solved this dilemma by working out of their homes. This may have involved sewing for private clients or a factory, taking in laundry or taking in lodgers or boarders. In $1900,58 \%$ of Portland's boarding and lodging housekeepers were widowed or divorced as were $21 \%$ of all dressmakers, and $30 \%$ of laundresses, although widowed and divorced women only comprised $15 \%$ of the female workforce. ${ }^{13}$ 
For the remainder of breadwinning women who had to work outside of the home, child care arrangements were needed. ${ }^{14}$ Some women working nights as a solution, they could care for their children and domestic duties during the day and go to work at night after their children were put to sleep. These women were constantly sleep deprived, but they were able to meet their domestic obligations and earn a wage while their youngsters were home alone sleeping. The only option for many other single mothers was to let their children look after one another while they worked. ${ }^{15}$ The low wages women earned and lack of available day care made life difficult for single working mothers. In a national Women's Bureau survey of working mothers, only one in twenty had paid childcare arrangements. Sometimes a neighbor was trusted to periodically check in on the kids if an older sibling or other relative was not available. Occasionally, children as young as five were responsible for looking after their younger siblings. A 1918 survey of working mothers in Philadelphia found that one third of children ages five to sixteen had no formal supervision. ${ }^{16}$ Only five percent of children nationwide in 1918 attended a day nursery.

During the early twentieth century, nurseries and kindergartens were just in their inception. In the first decade of the $1900 \mathrm{~s}$, most reformers assumed that working women were young, single and childless. For many native born white women this assumption was true. In Portland in 1900 , only $5.6 \%$ of married women worked. ${ }^{17}$ Thirty one percent of widows were employed as were $66.5 \%$ of divorced women. By the 1920s the numbers of married women in the labor force 
had doubled and popular perceptions of working women and reformers efforts began to expand their focus to include primarily white female breadwinners. In 1904 there was not one day nursery in the entire state of Oregon. ${ }^{18}$ By 1910 , the three Pacific coast states, Oregon, Washington and California, had the highest per capita numbers of state institutions caring for children in the nation. ${ }^{19}$

Children in the early part of the twentieth century contributed to the household's economy. In the early 1900s it was common for children aged 10-15 to be employed. The sons of widowed mothers more often went work and began at an earlier age than their counterparts raised in two parent families. A son as young as 10 to 14 years could commonly earn a higher wage than his mother could. Until the 1930 s working mothers were most likely to work while their children were young. Once their children reached working age, the mother could then return to her unpaid domestic work while the children contributed to the household income. Oregon's child labor law was enacted in 1912 and was accompanied by a concurrent attempt to increase expenditures and enrollment in public schools. ${ }^{20}$ From 1900 to1910, and again from 1910 to 1920 public school budgets doubled. Although public schools offered some supervision for children of working mothers, many single breadwinning women still could not afford to support their offspring on the meager wages they earned. A survival strategy of widows, abandoned wives and divorcees used was to temporarily give up custody of their children to relatives or institutions until they could afford to raise them again. One local institution young children were sent to was the Waverly Baby Home which 
cared for children under the age of three. In 1915, "the majority of those in the home were of respectable parentage, children of widowed mothers, dependent upon themselves for support or of fathers desolate and helpless when left with motherless babies, others are wholly orphans or friendless."21 The home noted the presence of illegitimate children in its care, but workers were careful to point out "not all illegitimate children are from degraded parents." Of the 1485 children the home had cared for since its incorporation in $1889,65 \%$ had two living parents, $30 \%$ had one living parent and only 5\% were actually orphans. Although 20\% were eventually adopted by another family, most had reunited with their parents by the time they turned three. Nationwide, seventy five percent of children were returned to their families, after an average stay of eighteen months in an orphanage. ${ }^{22}$

\section{Child Saving and the Development of the Mother's Pension} Indoor relief, or the institutionalization of children and other indigent populations, did not begin until the early to mid nineteenth century. In 1868 , Multnomah County followed the nationwide trend of replacing the outdoor relief system with an institutional form of relief called the poorhouse. ${ }^{23}$ When it first opened, the poorhouse served as a catch-all institution for the old, sick, disabled, mentally ill and families or individuals who lacked economic resources. It was the refuge of last resort for the poor and Multnomah County's Hillside Farm was known for its "deplorable" conditions. In the 1870 s and 1880 s a nationwide campaign successfully lobbied to remove children from the poorhouse. Although the policy of housing children among the sick and mentally ill was undesirable, the 
alternative removal of children form the poorhouse resulted in a policy of family break-up. ${ }^{24}$ New institutions emerged exclusively for the care of poor, abandoned, and orphaned children. The Ladies Relief Society established the first orphanage in Portland in 1872. It not only cared for orphans but also was responsible for assisting poor families by "taking their children and placing parents in the way of employment." 25

Throughout 1904, orphanages in Portland admitted 355 new children, although the poorhouse continued to care for a few minors. ${ }^{26}$ One young charge of the poorhouse was nicknamed John the Baptist. ${ }^{27}$ In 1902, this biracial son of an eastern Oregon banker's daughter was left on the steps of a Mt.Tabor Church. He quickly became a favorite in the baby's ward where he lived with three other youngsters. Other local agencies specialized in finding temporary and permanent homes for abused or neglected children. The Boys and Girls Aid Society of Portland found homes for an average of two children daily during the last few months of $1905^{28}$

The height of the family breakup policy occurred in 1910 . That year the six orphanages and children's aid societies in Oregon housed or cared for a total of 1265 children. ${ }^{29}$ In 1910 three out of every thousand children nationwide was institutionalized. ${ }^{30}$ The sharp declines in the numbers of institutionalized children after 1910 reflects the ideological shift that was occurring in the in the reform movement that Katz and others have labeled as "child saving."31 From 1870 to 1930 , the sentimental value of children increased in society as their economic 
importance to the middle class family declined with urbanization. This transformation in the role children played in family life helped create the concept of childhood, defined as a distinct life phase separate form adulthood.

In its beginnings, the child saving movement was focused on removing children from the "ecology" of poverty, which usually included their neighborhood and family. ${ }^{32}$ Groups such as the Children's Aid Society sent impoverished children from the city to farms states away. Ironically, many children who the organization thought they helped save from an early entry into factory work ended up becoming free agricultural labor on the farms they were sent to. Other children remained in the city but were sent to institutions or foster care. The child saving movement soon recognized the potential for abuses in the foster care and orphanage systems. In 1907, Multnomah County began inspecting and regulating institutions for children. ${ }^{33}$

In 1909, the White House held a national conference on the care of dependent children. This conference marks the ideological shift in the child saving movement from advocating family break-up to fighting for family preservation. The conference recommended that children not be removed from their homes because of poverty. Conference participants supported foster care options over large scale institutions. When large institutions were necessary, they recommended the cottage system to promote a more home like environment. The year following the White House Conference on Children marked the height of the 
institutionalization of children. After 1910, the numbers of children sent to institutions steadily fell. ${ }^{34}$

Preserving the family instead of breaking it up did not help solve the underlying economic problems that forced mothers to give up their children. After the White House Conference on Children, the National Conference of Mothers began advocating for a return to outdoor relief in the form of a mother's pension. ${ }^{35}$ In 1911, Illinois became the first state to enact a mother's pension, a small allowance that encouraged widowed women to stay at home with their children. Katz views the passage of the first mother's pension as a turning point in the child saving movement away from keeping children out of institutions to keeping mothers in the home.

The demand for a mother's pension in Oregon came from the same middle class women's clubs who also pushed for legislation to curb child labor and regulate women's working conditions. The Oregon Congress of Mothers led the effort to create a pension for "worthy and dependent mothers." 36 The Oregon Federation of Women's Clubs endorsed it and in 1913 Oregon joined twenty other western states by passing a mother's pension bill. Pensions of $\$ 10$ a month were given to mothers with one child and $\$ 7.50$ was added for each additional child. ${ }^{37} \mathrm{~A}$ judge in the newly created Court of Domestic Relations for Multnomah County administered it. In the first year of its existence, 136 widows received pensions in Multnomah County out of over 400 who applied. ${ }^{38}$ 
Although in its first year, the mother's pension program aided 136 women and 356 children, the legislation did not create an adequate social safety net for single mothers and their children. Across the nation, eligibility for pensions was primarily limited to widows. As a result, over $90 \%$ of recipients were widowed, only $5 \%$ had been abandoned or deserted by their husbands and just $1 \%$ went to divorced mothers. ${ }^{39}$ Oregon's law prohibited unwed mothers from receiving pension funds. However, wives of prisoners and other inmates were eligible for pension funds. In 1914, MZ received a mother's pension in Polk County to help support her five children while her husband was committed to a state institution. ${ }^{40}$ In addition to a preferential treatment for widows, there was a racial bias in the distribution of pension funds. While blacks made up only a small portion of Oregon's population, making it difficult to determine if racism was a factor in widow's relief, in counties across the nation where blacks were a majority, black single women did not receive their fair share of mother's pensions.

In addition to race and marital status, other criteria were used to judge potential mother's pension recipients. Women could be rejected for not regularly attending church, living in an "immoral" neighborhood, smoking, drinking or taking in male lodgers. ${ }^{41}$ Fulfillment of these criteria were determined by a "friendly visitor" met interviewed the applicant at home. In Multnomah County, applicants for mother's pensions were required to list all living nearby relatives who might provide them with monetary support and to give four character references. ${ }^{42}$ The applicant also had to furnish all of her financial information and 
allow a paid investigator to visit her home. The judge who granted pensions could compel women to move out of their neighborhood or evict their boarders. A committee comprised of middle class female volunteers from local clubs and PTAs reviewed the paid investigator's report and recommended a decision to the judge. If the pension was denied, as it was $66 \%$ of the time, the applicant was referred to local charities. ${ }^{43}$

One year after the passage of the mother's pension bill in Oregon, the Oregon Federation of Women's Clubs called for amendments to the original legislation because they believed "advantage is being taken of the statute by the undeserving." ${ }^{44}$ The proposed changes included instituting a preference for women with young children, capping the maximum allowance at $\$ 40$ a month, regardless of family size, and requiring pension applicants to have lived in Oregon for three years and in the county of application for one year. The clubwomen also wanted to more tightly regulate how women used their pension. They wanted to prohibit women from sharing their pension funds with relatives and to prevent them from using the money for any property improvements. The amendment also tightened the application process to make sure mothers were "mentally, morally and physically fit" and to deny pensions to families with a sick member who was not institutionalized.

In 1914, a judge considered allowing women to work and still receive a pension, but no action was taken. ${ }^{45}$ Mother's pensions were so small that it was close to impossible to survive on this meager relief without working. In Portland in 
1914 , Emily L. only received $\$ 20$ a month to support herself and four children. ${ }^{46}$ Anna $\mathrm{G}$. and her two children lived on $\$ 17.50$ a month during an era when reformers claimed the single working women needed at least $\$ 10$ a week to survive. In 1919, the second White House Conference on Children proclaimed that widow's pensions were inadequate. ${ }^{47}$ A 1923 study of 942 mother's pension recipients in nine cities found that $52 \%$ of the women who received funds continued to work. A 1926 study discovered that over one third of children aged 14 to 16 of mothers who received pensions were employed. This was a much higher rate of youth employment than existed in the general population.

Despite the racism and paternalism in the awarding of mother's pensions, this groundbreaking social welfare program paved the way for the Aid to Dependent Children's program in later decades. Although the grants given to single mothers were inadequate, the mother's pension program did help establish women's right to keep their children in the absence of a male breadwinner. ${ }^{48} \mathrm{By}$ $1921,121,000$ children and 45,000 women benefited from the mother's pensions programs nationwide. ${ }^{49}$ According to Ambramowitz, the most important legacy of the mother's pension program was the state sanctioning of women to the domestic sphere and the lasting precedent that set in later welfare programs. ${ }^{50}$

\section{Saving the Child, Institutionalizing the Woman: Indoor Relief for}

\section{Unwed Mothers}

Unmarried women with children were ineligible for mother's pensions, stigmatized by the community, often ostracized from their families and 
economically marginalized by their status as females in the labor force. Reformers who focused on improving the lives of single women ignored the problem of unwed motherhood. Limited charity funds and public welfare programs that benefited breadwinning women viewed unmarried mothers as "unworthy" and denied them access to relief funds or assistance. It was not uncommon for single mothers to give up their children to an orphanage, foster home or for adoption. In the early twentieth century few services existed for women before, during or after the birth of their child. Some went to for- profit maternity homes to give birth but these places were "filthy" just "hide-outs where some unfortunate girl goes into retirement and forgets to take her baby with her as she leaves..51

The clubwomen involved in the child saving movement soon recognized the need for a safe, clean place for single mothers to go to give birth and prepare for motherhood. The first groups to embrace the idea of a maternity home were religious. In Portland, the Salvation Army opened their Rescue Home at 762 North Vancouver Avenue in $1897 .{ }^{52}$ Although the home served all homeless and wayward women and children, many of those admitted were single mothers. In 1904, 125 women and 54 children were served in the Rescue Home.

Evangelical men and women were critical in the founding of the national Florence Crittenton Missions. The Florence Crittenton Missions began in 1883 in New York City founded and funded by the wealthy Charles Crittenton. ${ }^{53}$ After the premature death of his daughter Florence, Crittenton underwent a religious conversion and began evangelical rescue work among prostitutes. The Florence 
Crittenton Missions spread across the nation as Charles Crittenton went on speaking tours. By the early twentieth century, the missions were having difficulty attracting many prostitutes to their homes and they began to transform their missions and become maternity homes. By World War I, the homes primarily served unwed mothers.

The Portland Florence Crittenton Home originally opened as The Women's Refuge Home for Fallen Women and was run as a shelter for prostitutes by the W.C.T.U. ${ }^{54}$ In 1892, the home became associated with the national Florence Crittenton Homes. After a decade of disorganization, two moves, and a loss of government funding, the home reorganized and reopened its doors in 1904. That year the home served 56 women and 28 children. ${ }^{55}$

In 1908 a third home serving unwed mothers opened in Portland. The Louise Home was run by a local charity organization that also managed the Portland Commons, a homeless men's shelter. ${ }^{56}$ The original Louise Home was at the top of steep Cable Street in Goose Hollow and had room for 30 girls but could house 50 if needed. It accepted delinquent girls and prostitutes in addition to unmarried mothers. Another home began in 1909 on the east side of Portland, the Saint Elizabeth's Home run by the Sisters of John the Baptist. The four maternity homes in Portland sheltered a total of 170 women in $1910 .^{57}$

The sudden interest in unmarried motherhood and miniature building boom in maternity homes in Portland coincided with the ideological shift to family preservation in the child saving movement. When the Florence Crittenton Homes 
became a national organization in the late nineteenth century their mission was "to encourage destitute, homeless, depraved women and men to seek reformation of character" and to provide for those who've "been betrayed from the path of virtue and are sincerely willing to reform, temporary homes and employment until they can be restored to friends or established in honest industry." home was to save the soul through providing a social service. By the time the Louise Home was established, reformers' attitudes towards unwed mothers had changed. Rather than focusing on the sins of the mother, reformers hoped to redeem the child. The unwed mother was transformed in this process from a fallen girl to a woman who needed help climbing up the pedestal of motherhood. In 1913 a volunteer at the Louise Home wrote, "the abandoned mother is the least thought of, the least cared for of all human beings but there is good in her." ${ }^{59}$ Even the Florence Crittenton Homes had changed their attitudes. By 1910, president of the national organization, Kate Waller Barrett, was advocating equal opportunity for the children of unwed mothers, and fighting against labeling youngsters as "illegitimate."

Under Barrett's helm, the Florence Crittenton Homes operated on a program of "scientific motherhood," which idealized women's domestic roles while ignoring the realities of working class women's lives. ${ }^{61}$ Inmates at the Crittenton Home were encouraged to keep their babies and if they did, were required to stay at the home until the child was six months old. The home encouraged beast feeding because it was healthy for the child. For women who 
chose to give up their children, the home's emphasis on breast feeding was turned into an opportunity to earn $\$ 8$ to 10 a week as a wet nurse outside the home for middle class women who wanted their children to have the benefits of nursing without sacrificing their own time and energy. Florence Crittenton matrons taught domestic skills to the women they served and placed departing residents in domestic service positions. In 1904 the Florence Crittenton Home in Portland taught the girls "educated work" each evening, which included cutting muslin patterns to sew underclothes. Even with training, many women still found domestic employment difficult. In 1905, the Portland Florence Crittenton Home board of directors debated how Mamie, who "behaved badly to her employers" would affect future domestic work placements. ${ }^{62}$

The Florence Crittenton Home was not unique in its idealization of motherhood and its single minded focus on training for the domestic labor force. The Louise Home also placed many women in domestic positions upon their release, although some received training as seamstresses in an affiliated sewing school. ${ }^{63}$ Women entered the Louise Home three months before the birth of their children and stayed three months after. The home also accepted delinquent girls and in 1913 was so overcrowded serving 174 women and 70 babies that year that the state withdrew its funding. In 1915, the organization inherited the defunct St. Elizabeth's maternity home property on the suburban east side where they built a larger facility for girls, which included a maternity hospital and separate clinic and home for the treatment of venereal disease. At the new facility, residents rotated 
their chores each month between laundry, farm work, and sewing. The new campus included a building for the Alderwood School a facility where young women could continue their education, since pregnant girls were prohibited from attending public school.

Although the Crittenton and Louise Homes relegated the women they served to the domestic labor force, they did recognize and attempt to alleviate the challenges women faced raising their children alone. In 1904, the Florence Crittenton Home opened one of the first day nurseries in Portland. ${ }^{64}$ Over one hundred children were enrolled that year; priority went to the children of former residents. In 1914 during the height of the family preservation and child saving movement, the Pacific Coast Rescue Society, who operated the Louise Home, opened a day nursery at 129 N.W. $14^{\text {th }}$ Street. ${ }^{65}$ The Albertina Kerr Center was conceived as an alternative to an orphanage. Instead it provided day care for children of working mothers and respite care for single parents. The nursery soon expanded into an annex next door and became so crowded that neighbors began to complain about the "constant crying of children both day and night." In 1921, a larger building was constructed on N.E. $22^{\text {nd }}$ Avenue to house the expanded Albertina Kerr Center. The new facility still primarily offered day and respite care but also cared for abandoned or unwanted children.

The maternity home movement, like the organized boarding homes for women, attempted to create a home like atmosphere for their "homeless" residents. The primary concern of the women who ran maternity homes was to the replication 
of paternal authority and supervision over the women they served. Regina Kunzel describes the atmosphere in most maternity homes as governed by a "welter of regulations. ${ }^{.66}$ Women were not allowed to leave the home unsupervised, visitors were restricted and regulated, mail was censored, and even the way women dressed and styled their hair was subject to approval by the matron. All of these regulations were designed to force unwed mothers to conform to the reformer's middle class values and mores. The Florence Crittenton Home tried to compel their inmates to marry the father of their child but any marriage was "preferable to no marriage at all'. In 1904, at the Portland home, Victoria gave birth to a son and a man stepped forward who "exhibited determination to marry the mother" as soon as she recovered from the birth. ${ }^{67}$ When the Louise Home opened, the matrons not only tried to "compel mothers" to keep their children but also tried to force fathers to financially support them through marriage. ${ }^{68}$

Some women, such as Elsie, were "very anxious to conform to the rules of the home" and were subsequently deemed "worthy girls". ${ }^{69}$ Others, like Maud refused to wear the Crittenton Home uniform and were asked to leave. In the summer of 1904 a big stir was caused at the home when five girls left taking their babies with them. They threatened to run away if they were not allowed to leave. The board released them to the care of their relatives and worried that this action might affect other girls who were "not willing to comply with the rules". Helen, a young Finnish woman, exhibited such strong resistance to the authoritarian regulations of the home that the police were called to remove her. When they did 
not respond, the board drafted a letter to the mayor seeking "proper protection for the home".

In addition to the paternalistic control of daily life in maternity homes, rescue workers promoted and sought to uphold societal myths about premarital sex and unmarried pregnancies. Kunzel describes the intake process at early twentieth century maternity homes that inevitably asked how the woman became pregnant. ${ }^{70}$ Workers often translated women's experiences into their own middle class perceptions of gender and sexuality. Women's stories were told or retold by workers to incorporate the popular mythology of the "old, old story of seduction and abandonment." This mythology supported Victorian sexual mores and rationalized the "worthiness" of unmarried pregnant women. Ultimately this ideology perpetuated the hierarchical relationship between the rescuer and the victim and furthered middle class women's political ambitions through the idealization of motherhood in society.

\section{Forgotten Women: The Female Elderly Poor}

Motherhood, when combined with marriage, not only elevated the social worth of young women, it also ensured her care, as she grew older. Katz discovered that elderly widows were more likely to be cared for by friends or relatives than their male counterparts. ${ }^{71}$ However, when an older female was childless she was more likely to end up destitute or in the poorhouse. Three quarters of widowed women with one or fewer children ended up in almshouses in 1910. 
Although the Multnomah County Poor Farm began as a catch-all institution for the indigent poor of every age group, by the time the facility moved to its new location in Troutdale in 1911 , the majority of residents were elderly poor. ${ }^{72}$ Of the 211 residents who needed to be moved to the new location, 75 had to be transported in boxcars because they were bedridden. In 1928, only 40 of the 400 inmates at the farm were women and most of these were over 60 years old. ${ }^{73}$ Many destitute tried to avoid commitment to the farm, because conditions were so poor. There was no segregation of the sick or dying in the male or female wards. Residents were given one pat of butter at breakfast, which had to last throughout the meals of the day. The farm was rat infested and inmates were bored, the recreation area was kept locked except during church services and there were few books or playing cards. The bedridden were not well cared for either. ${ }^{74}$ Their bedding was only changed once a day and some had to wait longer than twenty four hours for a nurse's attention.

The poor farm was not the only institution that cared for the elderly poor. The Mt. Saint Joseph Home for the Aged opened in 1883 and the Patton Home was founded in $1887 .^{75}$ These two charities cared for 71 elderly patients in 1910,53 of which were women. Although conditions were better at the private charity nursing homes than they were at the poor farm, all three institutions tried to collect monthly payments from living relatives. The poor farm would accept inmates without payment as long as they appeared before a county judge and testified that they had no living relatives able to care for them. Poor farm inmates were compelled to 
work if physically able to. Men did farm labor and women cooked and washed laundry. In 1915, the dining room was divided into two sets of tables, the "mush" table for those who do not work and the "meat table" for those who do. ${ }^{76}$

Women tended to be underrepresented among the most destitute of the institutionalized elderly poor for two main reasons. Katz asserts that it was socially unacceptable for children to abandon their elderly mother, although a father could be expected to care for himself. ${ }^{77}$ The presumed dependency of older women also meant there was a greater availability of services for elderly females, which explains the overrepresentation of women in the private charitable old age homes. O.A.Johnson, superintendent of the Multnomah County Poor Farm for over a decade offered the following explanation for the farm's 7:1 male to female ratio: "A mother generally makes herself welcome in her children's home by assisting with the housework or sewing whereas an aged man frequently is only in the way." ${ }^{78}$ In other words, women's economic value as an unpaid domestic worker did not diminish with age, as men's value did in the paid labor force.

\section{Conclusions}

Women in the early 1900 s were valued for the unpaid labor they contributed to the household economy. The only women for whom it was socially acceptable to bring wages into the household were unmarried, young daughters. The wages these women earned were not adequate to even support a household of one. Single mothers, whether widowed, divorced or never married, faced the difficult challenge of trying to financially support their families on meager female 
wages while still maintaining their domestic responsibilities. This position eventually led to temporary family break-up for many single mothers and their children, which reinforced the patriarchal family as the only economically viable model.

The reform movements that founded maternity homes, won mother's pension legislation and initiated child saving policies did not challenge women's place in the home or society. The policies these movements won reinforced women's domestic roles. However, the black women and divorced or unmarried women who were excluded from mother's pension legislation were denied even the opportunity to fulfill their socially created roles of wife and mother. These "unworthy" mothers instead continued to struggle to raise their children on inadequate wages, attempt to juggle paid and unpaid responsibilities and face family break-up.

Women's value as unpaid laborers had its benefits. Elderly women were cared for within family structures as a form of household pension for their years of unpaid service. Mother's pensions placed an economic value on the work women did. However, these pitiful allowances did not promote equality between male and female laborers, instead they promoted a new form of dependency on the state, which was a poor substitute for a husband's wage. 
${ }^{1}$ Lynn Weiner, From Working Girl to Working Mother: The Female Labor Force in the Untied States from 1820-1980 (Chapel Hill: University of North Carolina Press, 1985), 26.

${ }^{2}$ Ruth Rosen, The Lost Sisterhood: Prostitution in America: 1900-1918, (Baltimore: Johns Hopkins University Press, 1982).

${ }^{3}$ U.S. Bureau of the Census, The $13^{\text {th }}$ Census of the United States, Population, $13^{\text {th }}$ Census Population, Table 10.

${ }^{4}$ U.S. Bureau of the Census, Census of Benevolent Institutions 1904, Temporary Homes-Oregon.

${ }^{5}$ The Portland Vice Commission, The Fourth Report of the Portland Vice Commission: A Report on the Economic Aspect of the Social Evil 1913, 199.

${ }^{6}$ Katherine G. Aiken, Harnessing the Power of Motherhood: the National Florence Crittenton Mission 1883-1925, (Knoxville: University of Tennessee Press, 1998), 70.

${ }^{7}$ Regina G. Kunzel, Fallen Women, Problem Girls: Unmarried Mothers and the Professionalization of Social Work 1890-1945, (New Haven: Yale University Press, 1993), 66-67.

${ }^{8}$ U.S. Bureau of the Census, Census of Benevolent Institutions, 1904, Temporary Homes, Oregon.

${ }^{9}$ The Consumers League of Oregon, Report of the Social Survey Committee of the Consumers League of Oregon on the Wages, Hours and Conditions of Work and Cost and Standard of Living of Women Wage Earners in Oregon, with Special Reference to Portland (Portland: National Consumers League, 1913), 21.

${ }^{10}$ Amelia Ann Feary, "The Origins and Development of Family Social Work in Portland Oregon,"(Master's thesis, University of Oregon, 1936) 47.

"U.S. Bureau of the Census, The $12^{\text {th }}$ U.S. Census of the United States 1900 Occupations, Table 43.

12 Ibid.

13 Tbid.

${ }^{14}$ Women's Bureau, 7.

${ }^{15}$ Tbid, 5.

${ }^{16}$ Weiner, From Working Girl to Working Mother, 121.

${ }^{17} 12^{\text {th }}$ U.S. Census Table 43.

${ }^{18}$ Census of Benevolent Institutions, 1904, Table XIII.

${ }^{19}$ U.S. Bureau of the Census, Census of Benevolent Institutions, 1910, Table 11, (OR, WA and CA had linstittuion for every 55,162 persons. These child caring institutions included orphanages, societies for the protection of children, homes for blind and sick children and day nurseries). 
${ }^{20}$ Sandra Haarsanger, Organized Womanhood: Cultural Politics in the Pacific Northwest, 1840-1920, (Norman: University of Oklahoma Press, 1997), 242.

${ }^{21}$ City of Portland Stanley Parr Archives and Records Center, Charity, Miscellaneous Baby Home, Waverly, A200-003, 14-06, 1915.

${ }^{22}$ Michael B. Katz, In the Shadow of the Poorhouse: A Social History of Welfare in America, (New York: Basic Books, 1996), 124.

${ }^{23}$ Sharon Nesbit, McMenamin's Vintage Edgefield: A History of Multnomah County Poor Farm, (Troutdale: McMenamins, 1995), 3-4.

${ }^{24} \mathrm{Katz}$, In the Shadow of the Poorhouse, 107-8.

${ }^{25}$ Feary, "The Origins and Development," 114-115.

${ }^{26}$ Census of Benevolent Institutions, 1904, Table 12.

27 "The Story of the Poor Farm," Oregon Journal, 4 August, 1902, 8.

28 "Children for Adoption," Oregonian, 23 October, 1905, 12.

${ }^{29}$ Census of Benevolent Institutions, 1910, Table 9.

${ }^{30}$ Mimi Ambramovitz, Regulating the Lives of Women: Social Welfare Policy

From Colonial Times to the Present (Boston: South End Press, 1988), 196.

${ }^{31} \mathrm{Katz}$, In the Shadow of the Poorhouse, 110-120.

${ }^{32}$ Ibid, 121-2.

${ }^{33}$ OR Historical Records Survey, Inventory of County Archives of Oregon, Multnomah County, Volume 1 Number 26, (Portland Or Federal Works Progress Agency, 1940), 169.

${ }^{34}$ Helena Znaniecka Lopata and Henry P. Brehm, Widows and Dependent Wives: From Social Problems to Federal Program (New York: Praeger Press, 1986), 4445.

${ }^{35} \mathrm{Katz}$, In the Shadow of the Poorhouse, 129-.133.

${ }^{36}$ Haarsanger, Organized Womanhood, 296.

${ }^{37}$ OR Historical Records Survey, 169.

38 "Widows Paid," Oregonian 13 September 1914, 15.

${ }^{39}$ Ambramowitz, Regulating the Lives of Women, 201.

40 "Pension Test Case," Oregonian, 27 September, 1914, p. 10.

${ }^{41}$ Znaniecka Lopata and Brehm, Widows and Dependent Wives, 47.

42 "Social Service", Oregon Journal, 16 August, 1914, p. 22

43 "Widows Paid", Oregonian 13 September, 1914, p. 15

44 "Mothers May Aid Pension Changes," Oregonian 18 October, 1914, p. 20

45 "Court and Pension Changes," Oregonian 17 December, 1914, p. 15

46 "Pensions Granted to Ten," Oregonian 5 may 1914, p. 15.

${ }^{47}$ Ambramowitz, Regulating the Lives of Women, 204.

${ }^{48}$ Znaniecka Lopata and Brehm, Widows and Dependent Wives, 48.

${ }^{49}$ Weiner, From Working Girl to Working Mother, 132.

${ }^{50}$ Ambramowitz, Regulating the Lives of Women, 204.

${ }^{51}$ City of Portland Stanley Parr Archives and Records Center, Mayor's Messages

and Municipal Reports, Health Department Report 1918, 1577.

${ }^{52}$ Census of Benevolent Institutions, 1904 Temporary Homes Oregon. 
${ }^{53}$ Otto Wilson, Fifty Years of Work with Girls: The Story of the Florence

Crittenton Homes 1883-1933 (Alexandria: National Florence Crittenton Mission, 1956), 30-60.

${ }_{55}^{54}$ Ibid, 415-417.

${ }^{55}$ Census of Benevolent Institutions, 1904, Temporary Homes -Oregon

${ }^{56}$ Rae Richen, To Serve Those Most in Need: A History of Albertina Kerr Centers, Portland: Albertina Kerr Centers (Portland: Albertina Kerr Centers, 1997), 15.

${ }^{57}$ Census of Benevolent Institutions, 1910 Temporary Homes-Oregon

${ }^{58}$ Wilson, Fifty Years of Work with Girls, 45.

${ }^{59}$ Richen, To Serve Those Most in Need, 20.

${ }^{60}$ Katherine G. Aiken, Harnessing the Power of Motherhood: the National

Florence Crittenton Mission 1883-1925 (Knoxville: University of Tennessee Press, 1998), 76

${ }^{61}$ Ibid, 75-87.

${ }^{62}$ University of Oregon Special Collections, Oregon Collection, Board Meeting Minutes, Florence Crittenton Home Portland Oregon 6/04, p. 52, 8/05, 131.

${ }^{63}$ Richen, To Serve Those Most in Need, 15-19, 37.

${ }^{64}$ Aiken, Harnessing the Power of Motherhood, 113.

${ }^{65}$ Richen, To Serve Those Most In Need, 23, 44-48.

${ }^{66}$ Kunzel, Fallen Women, Problem Girls, 30-32.

${ }^{67}$ Board Meeting Minutes, Florence Crittenton Home, Portland OR 4/19/04 p. 47.

${ }^{68}$ Richen, To Serve Those Most in Need, 19.

${ }^{69}$ Board Meeting Minutes, Florence Crittenton Home, Portland OR, 1/11/04, p.15, 12/30/04, p. 16, 7/04, p.55, 3/05, p.108.

${ }^{70}$ Kunzel, Fallen Women, Problem Girls, 22-23.

${ }^{71} \mathrm{Katz}$, In the Shadow of the Poorhouse, 90.

${ }_{73}^{72}$ Nesbit, McMenamin's Vintage Edgefield, 4.

${ }^{73}$ Multnomah County Archives, Poor Farm Correspondence 01-009.

${ }^{74}$ Multnomah County Archives, Poor Farm Records and Reports, H1 82-95 (21), 02-001.

${ }^{75}$ Census of Benevolent Institutions, 1910 Temporary Homes-Oregon

${ }^{76}$ Nesbit, McMenamin's Vintage Edgefield, 8.

${ }^{77} \mathrm{Katz}$, In the Shadow of the Poorhouse, 19.

${ }^{78}$ Multnomah County Archives, Poor Farm Historical Reports, Box H1 82-95 (22). 


\section{CONCLUSIONS}

There were many women in Portland who "left a family group and had yet identified with another" from 1900 until 1929. ${ }^{1}$ Single working women living independently, prostitutes, single mothers and their children, and elderly women without family to care for them were all associated with homelessness during this era. Women adrift best fit the era's definition of the female homeless; they were living apart from their family and were often tenuously housed. Prostitutes had strong ties to the male homeless community and were viewed as a threat to their gender and, like the hobos, to the urban social order. The 'half homeless' status of single women's children led to the consideration of widowed, divorced and unmarried mothers as part of the homeless population. Like single mothers, childless elderly women were economically marginalized in a society that only valued and rewarded women for their household and child rearing duties. These homeless women were primarily categorized as such because of their non-traditional family status, which contributed to their tenuous economic position.

For homeless women estrangement from the traditional family structure was akin to homeless men's disaffiliation from the labor market. During the industrial era, women entered new economic and familial relationships. Historian Carl Degler identifies these new relationships as the "first transformation" of the family. As wage labor arose the family moved from being a unit of production to becoming a unit of consumption. Although work within the family had always been divided between the sexes, the first transformation of the family had a gendered impact on women and 
men's relationship to the economy. Men's labor became economically productive and women and children's work was primarily consumptive. The function of the family unit changed as well, from a creator of goods and services necessary for survival to a redistributor of income.

Women's homelessness in the early twentieth century cannot be fully analyzed without understanding these economics of the household. Women did not just become homeless because of the sexual division of labor within the family, but because the labor market re-enforced gender roles by undervaluing women's work. Women workers, regardless of their family status, were paid salaries that were meant to supplement a male breadwinner's wages. ${ }^{3}$ Women adrift and single mothers were unable to survive as independent households because the labor market did not value them as such. Prostitutes were able to earn a higher income but reform movements eventually criminalized the commercialization of sex, because of the threat it posed to the traditional family and women's status in it.

Single men in the early twentieth century became homeless because they had a casual relationship to the labor market. The converse side to abundant seasonal and temporary work was bouts of unemployment, destitution, and homelessness. Men sought relief when they were too ill, injured, or old to earn a wage. However, homeless women were more likely to be full time workers than were their better off sisters. Most homeless women, whether adrift, single mothers or prostitutes were working. Unlike men, women's homelessness resulted not from their lack of employment but from their detachment to a household. 
The industrial era solutions proposed for homeless women rarely challenged gender roles; instead they sought to recreate the patriarchal authority of the family. Homes for working women were more concerned with prohibiting male visitors than creating a viable affordable housing alternative. Mother's pensions were not adequate enough to lift women out of poverty. Gwendolyn Mink argues that these maternalist policies gave value to women's work, but they did not alter traditional gender roles and ultimately transferred women's dependence from the husband to the state. ${ }^{4}$ The anti-vice campaigns that shut down the red light district first sought to rescue helpless women who had been forced into solicitation and later punished them for their actions.

Like relief for homeless men, homeless women's charities differentiated between the deserving and undeserving female poor. White, widowed women who allowed the state to supervise their personal lives were rewarded with outdoor relief, or cash grants in the form of mother's pensions. Divorced and unmarried mothers were deemed undeserving, because they chose to live outside of patriarchal family relationships, and they were forced to utilize indoor relief, or institutions such as orphanages or maternity homes. The primary aim of indoor relief was not the elimination of poverty, but rather the reform and control of the poor. Women adrift were socially suspect due to their single status and independence. Indoor relief in the form of boarding homes arose to serve this population. Protective labor legislation eventually performed the redistributive effect typical of outdoor relief, but these laws also sought to control single working women by limiting the hours and trades they could work in. ${ }^{5}$ 
Marxist-feminists interpret the economics of the family by focusing on the gender conflicts within this institution. According to Blau and Ferber, Marxistfeminists argue that the family is the "primary source of women's oppression and is a locus of struggle.." For many homeless women who lived outside of the traditional family, charity and relief workers became the patriarchal authority with whom they struggled. Women adrift had rejected the working women's homes by the $1920 \mathrm{~s}$ and created their own peer oriented culture to meet many of their social, emotional, and even economic needs. Prostitutes' existence was a threat to the traditional structure of the family. They commercialized wifely duties, therefore lowering the value of married women's most important bargaining chip. Unwed mothers may not have been on the front lines of the labor movement but their resistance to the matron's authority in maternity homes gave them more control over their individual life choices.

Middle class led women's movements were responsible for both the indoor and outdoor relief that arose to remedy women's homelessness. Middle class women defined the problem of female homelessness through the solutions they proposed to it. The staff/inmate clashes that eventually arose in these charitable institutions for homeless women reflected a class conflict between working class inmates and middle class administrators. Class tensions were also evident in the outdoor relief or social welfare legislation middle class women passed. Mother's pensions did not pay enough for women to survive on and anti-vice campaigns offered few real alternatives to prostitutes other than jail, the Cedars, or a poorly paid domestic position. Homeless women's status and living conditions rarely improved as a result of middle class 
intervention. The one exception was labor legislation, which although it limited women's participation in the labor force, it eventually culminated in minimum wage laws that provided enough income to maintain a basic standard of living for a single woman. This legislation, however, was influenced by a coalition of working and middle class women and still excluded the domestic labor force employed in many clubwomen's homes.

Lois Banner, Sandra Haarsanger and others contend that middle class women abandoned the causes of working class women after the got the right to vote in $1920{ }^{7}$ While many activist middle class women were genuinely concerned with the plight of their less fortunate sisters, clubwomen as a movement did not challenge the class structure. Reforms on the behalf of working class women were part of the larger campaign, women's suffrage. Many believed that when women were able to vote, the state would become more socially responsible. However once women were politically enfranchised they did not vote as bloc and the state became no more receptive to the needs of homeless women or the working class. ${ }^{8}$ Perhaps had a women's movement that was truly inclusive been forged, suffrage could have changed the face of U.S. social welfare policies. Instead U.S. social policies are "drawn by race and mediated by gender," thus obscuring class conflict. ${ }^{9}$

Social welfare continues to be inadequate and class based movements have declined over the past sixty years. Homelessness remains an enduring social problem and women are increasingly vulnerable to losing their housing. How does the incorporation of women into the history of homelessness help us understand the 
problem, as it exists today? Historical analysis not only offers a method to trace the development of policies and examine the changes in a population over time, it also allows the opportunity to uncover the structural mechanisms underlying persistent social problems.

A lot has changed for women since 1929. Instead of unpaid labor in the home, the majority of women, married and single, with children or without, now work in the paid labor force. As women's connection to the labor market improved, so did their power and autonomy in the household. Women are choosing not to marry, to divorce or raise children on their own, options that may have led to homelessness at the turn of the twentieth century.

Although progress has been made, women are still disproportionately poor and female work continues to be undervalued in the labor market. While domestic labor is no longer the primary female source of employment, many women remain trapped in traditionally low paying female occupational categories, such as clerical and retail trades. ${ }^{10}$ Single mothers still must try to survive on lower wages and attempt to find a balance between their hours devoted to paid and unpaid labor. Motherhood has yet to be valorized economically, socially or politically. ${ }^{11}$ The social safety net that had just begun to be woven in the early twentieth century is quickly becoming unraveled. Welfare benefits have become linked to work requirements and women are no longer compensated by the state for performing their unpaid household duties.

The exodus of women from the home to the workplace has not lessened the important role household economies continue to play in women's lives and the 
production of homelessness. "Although some of the antecedent conditions of homelessness are the same for women and men (e.g. poverty, the declining availability of affordable housing, mental health or addiction problems), unique factors related to being a woman contribute to the experience of poverty and homelessness." ${ }^{22}$ Many of these factors are the same as they were in 1900. Single parenthood, domestic violence, pregnancy, and wage inequities all raise women's risk of homelessness.

While the inequities within the household economy continue to play a role in the production of women's homelessness, our understanding of families and homelessness has changed significantly. Single working women are not considered homeless when they live on their own; rather they are respected for their independence. The notion of household has expanded to include single women or men, unmarried couples, same sex relationships, step children or parents and single parents. Homelessness is no longer defined in opposition to the traditional family, because the definition of family has changed so much. Now homelessness is defined as an economic state that describes a literal lack of housing or displacement from a permanent address.

The homeless men and women of the early twentieth century were destitute and although some lodged in police stations, or slept in parks or in missions, the majority of homeless people were sheltered. Housing costs and options have changed dramatically since the early twentieth century. In 1910, even an unemployed man could beg up enough change to rent an infested mattress in a flophouse for the night. Now housing has become a pricier commodity and the cheap varieties that could be 
purchased by the day or week are not as readily available. Unlike food, housing bills are usually paid in a monthly lump sum. There is little opportunity to go without housing for a day or to downgrade it with fluctuations of income. ${ }^{13}$ Instead of a dime for a bed, a potential renter must now have a first and last month's rent plus deposit and application fees and a clean credit record. The housing options available in the early 1900 s reflected the era's labor market. Workers were laid off with fluctuations in markets and production cycles and illness or injury could quickly lead to destitution. The housing market reflected the volatilities workers endured. If a household suffered a temporary loss of income they could take in boarders, move to a furnished room or send the children off to relatives until things got better.

Housing options today do not reflect the realities of work in a post-industrial society. Economic restructuring has led to work that is more often temporary, parttime and lacking in benefits and housing choices no longer reflect the instability of the market. The cost of housing and proportion of income spent on it has risen too. Rubin, Wright and Devine attribute the current wave of homelessness to the lack of affordable housing options. ${ }^{14}$

As housing affordability has declined, options for emergency and temporary housing of the homeless have increased and replaced the cheaper housing options the market once offered. Joanne Passaro identifies the gendered inequalities in the treatment of the homeless in these institutions. ${ }^{15}$ Homeless women continue to be patronized in the modern shelter system and are viewed as needy and dependent. If they exhibit the proper meek, docile and needy behavior that social service providers 
expect, they will be the "worthy" poor rewarded with housing. A failure to participate in this charade leaves homeless women in the same difficult position as homeless men. Gender constructs are equally restrictive to men's identity. Homeless men are simultaneously "hypermasculinized and demasculinized." Their absence from a family unit and for non-white men, their race, makes them threatening and potentially violent while at the same time their inability to get work or housing makes them unmanly. Passaro contends, "Homelessness is a problem about 'home', about the cultural gender imperatives that are created and reinforced by the ideology of the nuclear family."

The implications of incorporating an analysis of home back into the concept of homelessness do not lessen the important role economic issues play in the construction of the problem. Instead an analysis of home broadens the definition of the economic determinants of homelessness to include unpaid household duties. A non gendered reading of the structural causes of homelessness can better inform the solutions to the problem. Any solution to the problem of homelessness must begin with policies or structures that aim to redistribute the wealth of this nation more equitably. However, women will not benefit from redistributive policies if the structure of the household does not also change. Whether the policy solution is affordable housing or expansion of the welfare state, unpaid household work needs to be recognized, valued, and considered a viable option for both men and women.

Jonathan Kozol, Ralph da Costa Nunez, and others who have studied and worked with modern homeless women and children recommend that structural 
supports such as child care and health care be incorporated into the shelter system to relieve women of some of their household duties. ${ }^{16}$ While these social supports are well intentioned and necessary for many homeless women to obtain and maintain permanent housing under the current system, the provision of such supports must be done in a way that recognizes the strengths of homeless women. The experiences of homeless women in the early twentieth century Portland teach us that when reform movements are not led by the poor, they often do not benefit them. Middle class reformers continue to dominate the social service system and dictate policy changes that affect the poor. Deborah Connolly's research among modern day homeless mothers reveals that middle class parenting values are imposed on women in the shelter system and that homeless mothers are "automatically under suspicion." Instead of reforming the poor, social support systems need to strengthen the indigenous support networks that already exist among the homeless. ${ }^{18}$ Just as the peer oriented subcultures provided economic and social support for women adrift, today's homeless communities have a long tradition of mutual aid and self-help. Top down solutions to homelessness among either gender will only perpetuate an inequitable class system.

Finally the incorporation of women into the historical narrative of homelessness provides an opportunity to examine the role the homelessness plays in U.S. society. Since male homelessness is so intertwined with the structure, fluctuations and flaws in the labor market, homelessness functions as a threat that keeps low wage workers from challenging their economic situation. To women, 
homelessness also serves to perpetuate the patriarchal family. Women are forced to choose between staying in an abusive relationship or homelessness. Forging nongendered solutions to homelessness can empower the working class and change the inequitable relationships that continue to exist in U.S. households.

${ }^{1}$ Anne Solenberger, One Thousand Homeless Men (New York: Russell Sage Foundation, 1911), 3.

${ }^{2}$ Carl Degler, At Odds: Women and the Family in America from the Revolution to the Present (New York: Oxford University Press, 1980).

${ }^{3}$ Francine D. Blau and Marianne A. Ferber, The Economics of Women, Men and Work (Englewood Cliffs: Prentice Hall, 1986).

${ }^{4}$ Gwendolyn Mink, The Wages of Motherhood: Inequality in the Welfare State 19171942 (Ithaca: Cornell University Press, 1995), 152.

${ }^{5}$ Mink, The Wages of Motherhood, 154.

${ }^{6}$ Blau and Ferber, The Economics of Women, 52

${ }^{7}$ Sandra Haarsanger, Organized Womanhood: Cultural Politics in the Pacific Northwest 1840-1920, (Norman: University of Oklahoma Press, 1997), 298, and Lois Banner, Women in Modern America: A Brief History, (New York: Harcourt Brace, Javanovich Inc. 1974), 158

${ }^{8}$ Linda Gordon, "The New Feminist Scholarship on the Welfare State", ed. Linda Gordon, Women, The State and Welfare, (Madison: University of Wisconsin Press, 1990), 74.

${ }^{9}$ Gwendolyn Mink, "The Lady and the Tramp: Gender Race and the Origins of the American Welfare State" ed. Linda Gordon, Women, The State and Welfare, (Madison: University of Wisconsin Press, 1990), 94.

${ }^{10}$ Randy Abelda and Chris Tilly, Glass Ceilings and Bottomless Pits: Women's Work and Women's Poverty (Boston: South End Press, 1997), 4.

${ }^{11}$ For a discussion of the current politics of motherhood see Ann Crittenden, The Price of Motherhood: Why the Most Important Job in the World is Still the Least Valued (New York: Metropolitan Books, 2001).

${ }_{12}$ Joan H. Rollins, Renee N. Saris and Ingrid Johnston-Robeldo, "Low Income Women Speak Out about Housing: A High Stakes Game of Musical Chairs", Journal of Social Issues, 57: 2, (2001), 279.

${ }^{13}$ Jonathan Kozol, Rachel and Her Children (New York: Crown Publishers 1988), 12. ${ }^{14}$ B.A. Rubin, J.D. Wright and J.A. Devine, Beside the Golden Door: Policy, Politics and the Homeless, (New York: Aedine de Gruyter, 1998).

${ }^{15}$ Joanne Passaro, The Unequal Homeless: Men on the Streets and Women in their Place (New York: Routledge, 1996), 1-3 
${ }^{16}$ Jonathan Kozol, Rachel and Her Children: Homeless Families in America (New York: Crown Publishers Inc, 1988), 234; Ralph de Costa Nunez, The New Poverty: Homeless Families in America (New York: Insight Books, 1996), 24.

${ }^{17}$ Deborah R. Connolly, Homeless Mothers: Face to Face with Women and Poverty (Minneapolis: University of Minnesota Press, 2000), 45.

${ }^{18}$ For studies about community among the homeless see David Wagner, Checkerboard Square: Culture and Resistance in a Homeless Community (Boulder: Westview Press, 1993) or Gwendolyn A. Dordick, Something Left to Lose: Personal Relations and Survival Among New York's Homeless (Philadelphia: Temple University Press, 1997). 


\section{REFERENCES}

\section{PRIMARY SOUCES}

$\underline{\text { Archives }}$

City of Portland Stanley Parr Archives and Records Center

Mayor's Messages and Municipal Reports, 1900-1929

Mayor's Official Correspondence, Subject Files, 1900-1929

Portland City Ordinances

Reports of the Portland Vice Commission, 1912-1913

Cheney Reports, 1919

Multnomah County Archives

Multnomah County Poor Farm, Records and Reports

Multnomah County Poor Farm, Correspondence

University of Oregon Special Collections

Oregon Collection, Board Meeting Minutes, Florence Crittenton Home, Portland Oregon 1904-1910

\section{Census}

$12^{\text {th }}$ Census of the United States, 1900

Census of Benevolent Institutions, 1904, 1910

$13^{\text {th }}$ Census of the United States, 1910

$14^{\text {th }}$ Census of the United States, 1920

Newspapers

Oregonian, $1900-1929$ 
Oregon Journal, 1900-1929

Published Reports

Consumers League of Oregon. Report of the Social Survey Committee of the Consumers League of Oregon on the Wages, Hours and Conditions of Work and Standard of Living of Women Wage Earners in Oregon with Special Reference to Portland. Portland: National Consumers League, 1913.

Oregon Historical Records Survey, Inventory of County Archives of Oregon, Multnomah County, Volume 1 Number. Portland: Oregon Federal Works Progress Agency, 1940.

U.S. Department of Labor Women's Bureau. Bulletin \#36: Radio Talks on Women in Industry. Washington: Government Printing Office, 1924.

U.S. Department of Labor Women's Bureau. Bulletin \#39:Domestic Workers and Their Employment Relations: A Study Based on the Records of the Domestic Efficiency Association of Baltimore, Maryland. Washington: Government Printing Office, 1924.

\section{SECONDARY SOURCES}

Abbott, Carl. Portland: Gateway to the Northwest. Tarzana CA: American Historical Press, 1997. 1981.

. The Great Extravaganza. Portland: Oregon Historical Society,

Abelda, Randy and Chris Tilly. Glass Ceilings and Bottomless Pits: Women's Work, Women's Poverty. Boston: South End Press, 1997.

Aiken, Katherine G. Harnessing the Power of Motherhood: the National Florence Crittenton Mission 1883-1925. Knoxville: University of Tennessee Press, 1998.

Allsop, Kenneth. Hard Travelin': The Hobo and His History. London: Hadden and Stroughton, 1967.

Ambramovitz, Mimi. Regulating the Lives of Women: Social Welfare Policy From Colonial Times to the Present. Boston: South End Press, 1988.

Anderson, Nels. The Hobo: Sociology of the Homeless Man. Chicago: University of Chicago Press, 1923. 
Bahr, Howard M. Skid Row: An Introduction to Disaffiliation. New York: Oxford University Press, 1973.

Banner, Lois W. Women in Modern America: A Brief History. New York: Harcourt Brace Jovanovich Inc., 1974.

Blau, Francine D. and Marianne A. Ferber. The Economics of Women, Men and Work. Englewood Cliffs: Prentice Hall, 1986.

Blau, Joel. The Visible Poor: Homelessness in the United States. New York: Oxford University Press, 1992.

Bogue, Donald J. Skid Row in American Cities. Chicago: University of Chicago Press, 1963.

Burt, Martha R. Over the Edge: The Growth of Homelessness in the 1980s. New York: Russell Sage Foundation, 1992.

da Costa Nunez, Ralph. The New Poverty: Homeless Families in America. New York: Insight Books, 1996.

Connolly, Deborah R. Homeless Mothers: Face to Face with Women and Poverty. Minneapolis: University of Minnesota Press, 2000.

Crittenden, Ann. The Price of Motherhood: Why the Most Important Job in the World is Still the Least Valued. New York: Metropolitan Books, 2001.

Degler, Carl. At Odds: Women and the Family in America from the Revolution to the Present. New York: Oxford University Press, 1980.

Dordick, Gwendolyn A. Something Left to Lose: Personal Relations and Survival Among New York's Homeless. Philadelphia: Temple University Press, 1997.

Feary, Amelia Ann. "The Origins and Development of Family Social Work in Portland Oregon." Master's Thesis, University of Oregon, 1936.

Gaston, Joseph. Portland: It's History and Its Builders. Chicago: S.J. Clarke Co., 1911.

Golden, Stephanie. The Women Outside: Meanings and Myths of Homelessness. Berkeley: University of California Press, 1992. 
Gordon, Linda. Women, The State and Welfare, (Madison: University of Wisconsin Press, 1990.

Groth, Paul. Living Downtown: The History of Residential Hotels in the United States. Berkeley: University of California Press, 1994.

Haarsager, Sandra. Organized Womanhood: Cultural Politics in the Pacific Northwest, 1840-1920. Norman: University of Oklahoma Press 1997.

Harris, Maxine. Sisters of the Shadow. Norman OK: University of Oklahoma Press, 1991.

Hobson, Barbara Mel. Uneasy Virtue: The Politics of Prostitution and the American Reform Tradition. New York: Basic Books, 1989.

Israel, Betty. Bachelor Girl: The Secret History of the Single Woman in the Twentieth Century. New York: Harper Collins 2002.

Katz, Michael B. In the Shadow of the Poorhouse: A Social History of Welfare in America. Basic Books: New York, 1996.

Kozol, Jonathan. Rachel and Her Children. New York: Crown Publishers 1988.

Kunzel, Regina G. Fallen Women, Problem Girls: Unmarried Mothers and the Professionalization of Social Work 1890-1945. New Haven: Yale University Press, 1993.

Kusmer, Kenneth L. Down and Out and On the Road: The Homeless in American History. New York: Oxford University Press, 2002.

Mac Coll, E. Kimbark. The Shaping of a City: Business and Politics in Portland OR 1885-1915. Portland: The Georgian Press, 1976.

Mac Lagan, Elizabeth. Peculiar Paradise: A History of Blacks in Oregon 17881940. Portland: The Georgian Press, 1980.

Meyerowitz, Joanne. Women Adrift: Independent Wage Earners in Chicago 18801930. Chicago: University of Chicago Press, 1988.

Miller, Henry L. On the Fringe: The Dispossessed in America. Lexington MA: Lexington Books, 1991.

Mink, Gwendolyn. The Wages of Motherhood: Inequality in the Welfare State 1917-1942. Ithaca: Comell University Press, 1995. 
Monkonnen, Eric H. Walking to Work: Tramps in America, 1790-1935. Lincoln: University of Nebraska Press, 1984.

Myers, Gloria Elizabeth. "Lola G. Baldwin and the Professionalization of Women's Police Work. 1905-1922." Master's thesis, Portland State University, 1993.

Nesbit, Sharon. McMenamin's Vintage Edgefield: A History of Multnomah County Poor Farm. Troutdale: McMenamins, 1995.

Pasarro, Joanne. The Unequal Homeless: Men on the Streets, Women in Their Place. New York: Routledge Press, 1996.

Reitman, Ben L. Boxcar Bertha: An Autobiography as Told To Dr. Ben L. Reitman. New York: Amok Press, 1988.

Richen, Rae. To Serve Those Most in Need: A History of Albertina Kerr Centers, Portland: Albertina Kerr Centers. Portland: Albertina Kerr Centers, 1997.

Rollins, Joan H, Renee N. Saris and Ingrid Johnston-Robeldo. "Low Income Women Speak Out About Housing: A High Stakes Game of Musical Chairs." Journal of Social Issues, 57, 2 (2001): 277-294.

Rosen, Ruth. The Lost Sisterhood: Prostitution in America 1900-1918. Baltimore: Johns Hopkins University Press 1982.

Rossi, Peter L. Down and Out in America: The Origins of Homelessness. Chicago: University of Chicago Press, 1989.

St Anthony's Foundation. Fact Sheet on Women and Homelessness. San Francisco: St. Anthony's Foundation, 1999.

Sawyer, Chris D. "From Whitechapel to Old Town: The Life and Death of the Skid Row District in Portland Oregon." Ph.D. dissertation, Portland State University, 1985.

Solenberger, Anne. One Thousand Homeless Men. New York: Russell Sage Foundation: 1911.

Spain, Daphne. How Women Saved the City. Minneapolis: University of Minnesota Press, 2001.

Steinbeck, John. The Grapes of Wrath. New York: Penguin Books, 1939. 
Sutherland, Donald E. Americans and Their Servants: Domestic Service in the U.S. from 1800-1920. Baton Rogue: Louisiana State University Press, 1981.

Wagner, David. Checkerboard Square: Culture and Resistance in a Homeless Community. Boulder: Westview Press, 1993.

Wardhough, Julia. "The Unaccomodated Woman: Home, Homelessness and Identity." Sociological Review (1999): 91-109.

Weiner, Lynn. From Working Girl to Working Mother: The Female Labor Force in the United States 1820-1980. Chapel Hill: University of North Carolina Press, 1985.

Wilson, Otto. Fifty Years of Work with Girls: The Story of the Florence Crittenton Homes 1883-1933. Alexandria: National Florence Crittenton Mission, 1956.

Wright, James D. and Jennifer A. Lam. "Homelessness and Low Income Housing Supply." Social Policy, (Spring 1987): 48-53.

Znaniecka Lopata, Helena and Henry P. Brehm. Widows and Dependent Wives: From Social Problem to Federal Program. New York: Praeger, 1986. 